\title{
Prokaryotic communities from a lava tube cave in La Palma Island (Spain) are involved in the biogeochemical cycle of major elements
}

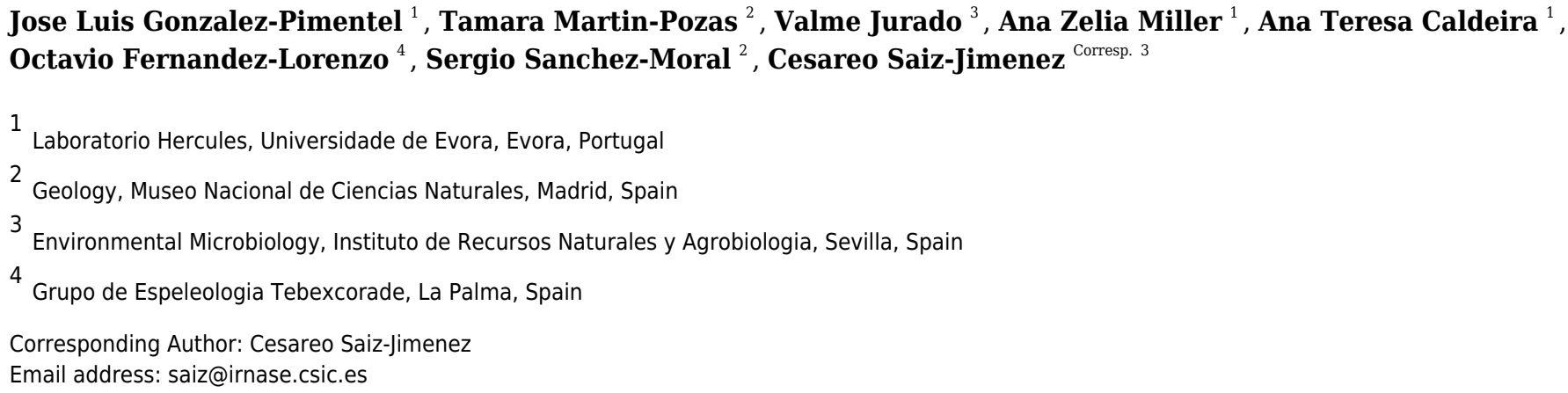

Lava caves differ from karstic caves in their genesis and mineral composition. Subsurface microbiology of lava tube caves in Canary Islands, a volcanic archipelago in the Atlantic Ocean, is largely unknown. We have focused the investigation in a representative lava tube cave, Fuente de la Canaria Cave, in La Palma Island, Spain, which presents different types of speleothems and colored microbial mats. Four samples collected in this cave were studied using DNA next-generation sequencing and field emission scanning electron microscopy for bacterial identification, functional profiling, and morphological characterization. The data showed an almost exclusive dominance of Bacteria over Archaea. The distribution in phyla revealed a majority abundance of Proteobacteria (37-89\%), followed by Actinobacteria, Acidobacteria and Candidatus Rokubacteria. These four phyla comprised a total relative abundance of $72-96 \%$. The main ecological functions in the microbial communities were chemoheterotrophy, methanotrophy, sulfur and nitrogen metabolisms, and $\mathrm{CO}_{2}$ fixation; although other ecological functions were outlined. Genome annotations of the especially representative taxon Ga0077536 (about 71\% of abundance in moonmilk) predicted the presence of genes involved in $\mathrm{CO}_{2}$ fixation, formaldehyde consumption, sulfur and nitrogen metabolisms, and microbially-induced carbonate precipitation. The detection of several putative lineages associated with $\mathrm{C}, \mathrm{N}, \mathrm{S}$, Fe and $\mathrm{Mn}$ indicates that Fuente de la Canaria Cave basalts are colonized by metabolically diverse prokaryotic communities involved in the biogeochemical cycling of major elements. 


\title{
2 Prokaryotic communities from a lava tube cave in La Palma
}

3 Island (Spain) are involved in the biogeochemical cycle of

4 major elements

5

6

7

\section{8} 9 10

Jose Luis Gonzalez-Pimentel ${ }^{1}$, Tamara Martin-Pozas ${ }^{2}$, Valme Jurado ${ }^{3}$, Ana Zelia Miller ${ }^{1}$, Ana Teresa Caldeira ${ }^{1}$, Octavio Fernandez-Lorenzo ${ }^{4}$, Sergio Sanchez-Moral ${ }^{2}$ and Cesareo SaizJimenez $^{3}$

\section{${ }^{1}$ Laboratorio HERCULES, Universidade de Evora, Evora, Portugal}

${ }^{2}$ Museo Nacional de Ciencias Naturales (MNCN-CSIC), Madrid, Spain

${ }^{3}$ Instituto de Recursos Naturales y Agrobiologia (IRNAS-CSIC), Sevilla, Spain

${ }^{4}$ Grupo de Espeleologia Tebexcorade, La Palma, Spain

Corresponding Author:

Cesareo Saiz-Jimenez

Instituto de Recursos Naturales y Agrobiologia (IRNAS-CSIC), 41012 Sevilla, Spain Email address: saiz@irnase.csic.es

\begin{abstract}
Lava caves differ from karstic caves in their genesis and mineral composition. Subsurface microbiology of lava tube caves in Canary Islands, a volcanic archipelago in the Atlantic Ocean, is largely unknown. We have focused the investigation in a representative lava tube cave, Fuente de la Canaria Cave, in La Palma Island, Spain, which presents different types of speleothems and colored microbial mats. Four samples collected in this cave were studied using DNA nextgeneration sequencing and field emission scanning electron microscopy for bacterial identification, functional profiling, and morphological characterization. The data showed an almost exclusive dominance of Bacteria over Archaea. The distribution in phyla revealed a majority abundance of Proteobacteria (37-89\%), followed by Actinobacteria, Acidobacteria and Candidatus Rokubacteria. These four phyla comprised a total relative abundance of $72-96 \%$. The main ecological functions in the microbial communities were chemoheterotrophy, methanotrophy, sulfur and nitrogen metabolisms, and $\mathrm{CO}_{2}$ fixation; although other ecological functions were outlined. Genome annotations of the especially representative taxon $\mathrm{Ga} 0077536$ (about $71 \%$ of abundance in moonmilk) predicted the presence of genes involved in $\mathrm{CO}_{2}$ fixation, formaldehyde consumption, sulfur and nitrogen metabolisms, and microbially-induced carbonate precipitation. The detection of several putative lineages associated with $\mathrm{C}, \mathrm{N}, \mathrm{S}, \mathrm{Fe}$
\end{abstract}


38

39

40

41

42

43

44

45

46

47

48

49

50

51

52

53

54

55

56

57

58

59

60

61

62

63

64

65

66

67

68

69

70

71

72

73

74

75

76

77

and Mn indicates that Fuente de la Canaria Cave basalts are colonized by metabolically diverse prokaryotic communities involved in the biogeochemical cycling of major elements.

\section{Introduction}

Lava tube caves are formed as a result of surface solidification of a lava flow during the last stages of volcanic activity. A decreasing supply of lava may then cause the molten material to drain out from under this crust and leave long cylindrical tunnels or caves. In spite of the existence of abundant literature on the tectonism, volcanism and geology of volcanic ocean islands (Carracedo \& Troll, 2016; Beier, Haase \& Brandl, 2018), the microbiology of lava tube caves was a topic scarcely studied in the first decade of the present century (Northup et al., 2004; Snider et al., 2009; Snider, 2010). However, in this decade lava tube caves become a hot spot for microbiologists, among other reasons by the interest in the search ofo recognizable biosignatures useful as astrobiology models due to the analogy of Earth volcanic lava caves with those of Mars (Perkins, 2020).

A large number of studies on the microbiology of lava tube caves have been dedicated to Hawai'i (Northup et al., 2011; Hathaway et al., 2014b; Riquelme et al., 2015b; Spilde et al., 2016) and other USA states (Northup et al., 2011; Popa et al., 2012; Riquelme et al., 2015a; Lavoie et al., 2017) and Azores Islands (De los Ríos et al., 2011; Northup et al., 2011; Hathaway et al., 2014a,b; Riquelme et al., 2015a,b). A few studies were also published on lava tube caves from Mexico, Galápagos and Easter islands (Luis-Vargas et al., 2019; Miller et al., 2014, 2020b).

The Canary Islands, Spain, is a volcanically active archipelago with eleven islands and islets, located in the Macaronesia region. The last eruptions occurred in La Palma (1971) and in El Hierro islands (2011-2012). In spite of the importance of this archipelago, geomicrobiological study of Canary Islands lave tube caves are rare (Gonzalez-Pimentel, 2019; Gonzalez-Pimentel et al. 2018).

The data reported on microbial diversity of lava tube caves in other volcanic islands need to be contrasted with those obtained for the relatively unknown lava tube caves from the Canary Islands, and so we focused the investigation in Fuente de la Canaria Cave, a representative lava tube cave with different types of speleothems and microbial mats. It is expected that the diversity of studied niches in this volcanic cave will shed light on the microbiology of lava tube caves from La Palma Island and will permit a comparison with other previously studied oceanic volcanic caves.

\section{Materials \& Methods}

Geological context and research background

La Palma Island $\left(28^{\circ} 40^{\prime} \mathrm{N}, 17^{\circ} 52^{\prime} \mathrm{W}\right)$ is located in the northwest of the Canary archipelago. The geology of La Palma was extensively described by Carracedo et al. (2001). This island shows a particular topography, characterized by the volcanos Taburiente and Cumbre Vieja which were separated by a valley. Cumbre Vieja is a volcanic ridge formed by numerous volcanic cones built 
78

79

80

81

82

83

84

85

86

87

88

89

90

91

92

93

94

95

96

97

98

99

100

101

102

103

104

105

106

107

108

109

110

111

112

113

114

115

116

117

of lava and scoria, developed over the past 150,000 years at the southern part of the island. The volcano is still active and the last eruption occurred in 1971 at the Teneguía vent, at the southern end of the Cumbre Vieja (Carracedo \& Troll, 2016).

Fernández Lorenzo (2007) compiled 135 lava tube caves in La Palma. However, in the last years the number increased due to the continuous discovering of new lava tube caves. The lava tube cave studied, Fuente de la Canaria Cave, is located in the Cumbre Vieja volcano area, which is characterized by the predominance of alkaline-dominated basaltic lavas (Klügel, Hansteen, \& Galipp, 2005).

Miller et al., (2020a) described the climate of La Palma Island as very mild and sunny most of the year, with rainfalls in autumn and winter. Humid northeast trade winds combined with the altitude and northwest dry winds produce an inversion layer originating a laurel forest with a great floristic diversity.

Fuente de la Canaria Cave is located in Villa de Mazo, southeast of La Palma Island (Fig. 1). The cave, with a length of $237 \mathrm{~m}$, is located a few hundred meters in a southwest direction of the Vinijore mountain, close to La Sabina neighborhood (Supplemental Fig. 1), at an altitude of 700 meters above sea level (U.T.M. 28RBS267654) (Dumpiérrez et al., 1997).

In La Palma Island, forests have been naturally affected by wildfires for centuries and torrential rains after the fires were frequent. In the period 2000-2017, 343 wildfires affected this island. On August 4, 2012 a fire in the municipality of Villa de Mazo destroyed 2,028 Ha, and affected Fuente de la Canaria surface area (Supplemental Fig. 1), resulting in extensive forest devastation and soil erosion. Transport of soil organic matter and ashes into caves were favored by the low thickness of the topsoil and the porosity of the basalts (Miller et al., 2020a). In addition, the cave shows wide shrinkage cracks and a continuous drip of water from the ceiling, from which the cave owes its name (fountain: fuente).

The entrance to the cave is a jameo (a large opening in the lava tube cave made by the partial collapse of the ceiling) (Figure 1). This entrance is about $3.5 \mathrm{~m}$ long by more than $1 \mathrm{~m}$ wide and inside grows a well-developed specimen of the tree heath Erica arborea. Once inside the cave, abundant herbaceous vegetation is noticed in the entrance ground with the presence of the invasive Mexican hygrophile plant Ageratina adenophora (Dumpiérrez et al., 1997). The cave walls present different light to dark brown mucous speleothems and rock walls widely coated by moonmilk and microorganisms (Fig. 2 and Supplemental Fig. 2).

\section{Sampling}

Samples were collected in 2015 (MZ03-2B, MZ03-3C, MZ03-8H) and 2016 (MZ03-10J) from the basaltic lava tube cave walls of Fuente de la Canaria Cave in La Palma Island (Canary Islands, Spain) (Fig. 1). Field experiments in La Palma Island caves were approved in project CGL2013-41674-P from the Spanish Ministry of Economy and Competitiveness. The cave temperature was $13.5^{\circ} \mathrm{C}$ and the relative humidity $90.5 \%$ at the sampling time. Microbial mats and mineral deposits were collected using sterile scalpels and stored in sterile $50 \mathrm{ml}$ tube caves. The samples were preserved at $4^{\circ} \mathrm{C}$ until arrival at the laboratory and then stored at $-80^{\circ} \mathrm{C}$.

Peer) reviewing PDF | (2021:02:58418:1:1:NEW 7 Apr 2021) 
118

119

120

121

122

123

124

125

126

127

128

129

130

131

132

133

134

135

136

137

138

139

140

141

142

143

144

145

146

147

148

149

150

151

152

153

154

155

156

157

A total of four areas were sampled along the cave length, comprising light brown to orange jelly-like secondary mineral deposits developing on the cave walls. Mineral deposits (moonmilk) and microbial colonies were spread all over the wall surface (Fig. 1 and Supplemental Fig. 2). The characteristics of the samples were as follows: MZ03-2B corresponded to a mucous formation of ochre color; MZ03-3C was an ochre soft stalactite: MZ03-8H an ochre mucous deposit on a rock crack with water runoff; MZ03-10J a mineral formation with abundant moonmilk deposits, extensively represented in the lava tube cave walls.

Field emission scanning electron microscopy

Samples were dried at $50^{\circ} \mathrm{C}$ for $24 \mathrm{~h}$, treated and examined in a Jeol JSM-7001F field emission scanning electron microscope as reported by Riquelme et al. (2015b).

DNA extraction, sequencing and phylogenetic analysis

Genomic DNA was extracted from 250 or $500 \mathrm{mg}$ as described elsewhere (Jurado et al., 2020a). The DNA concentration was quantified using a Qubit 2.0 fluorometer (Invitrogen, Carlsbad, CA, USA) in order to reach a minimum of $100 \mathrm{ng} / \mathrm{sample}$.

DNA was analyzed by Next Generation Sequencing. We focused on V3 and V4 regions of the 16S rRNA gene using 341F (CCTACGGGNGGCWGCAG) and 805R

(GACTACHVGGGTATCTAATCC) primers (Jurado et al., 2020a). Sequencing was carried out by means of the Illumina MiSeq platform. Amplicon library for samples MZ03-2B, MZ03-3C and MZ03-8H was constructed by Macrogen (Seoul, Korea) for $2 \times 250$ paired-end sequencing, according to the Illumina metagenomic library preparation protocol, whereas MZ03-10J amplicon library construction was carried out by STAB Vida sequencing services (Portugal) for $2 \times 300$ paired-end sequencing.

Quality control and trimming of raw data was processed using FASTQC (http://www.bioinformatics.babraham.ac.uk/projects/fastqc/) and Trimmomatic (0.36 version) (Bolger, Lohse \& Usadel, 2014), respectively. Paired-end reads were assembled using PEAR (Zhang et al., 2014). QIIME 1.9.1 was used for subsequent analyses (Caporaso et al., 2007). Operational Taxonomic Units (OTUs) were clustered at 97\% cutoff using UCLUST (Edgar, 2010). SILVA database for bacteria (version 132) (Quast et al., 2013) for taxonomic identification of $16 \mathrm{~S}$ rRNA gene sequences (threshold of 80\%), heat-maps built in R using gplots package (Warnes et al., 2015), and alpha diversity metrics were used as reported by Jurado et al. (2020a).

Represented samples in heat-maps were reordered with dendrograms based on the row and column mean values as described by the authors. The raw reads were deposited into the NCBI Sequence Read Archive (SRA) database under the accession numbers ERX3225013, ERX3225015, ERX3225016 and SRX9462704.

Ecological function of samples was investigated with the "functional annotation of prokaryotic taxa" software, which employs a manually curated functional annotation database based on the literature of cultured representatives of soil and marine microbiomes (Louca, 
158

159

160

161

162

163

164

165

166

167

168

169

170

171

172

173

174

175

176

177

178

179

180

181

182

183

184

185

186

187

188

189

190

191

192

193

194

195

196

197

Parfrey \& Doebeli, 2016). A bubble plot illustrating the data was generated using the "ggplot2" library in R package.

The ecological role of microbial comunities was also predicted with a bioinformatics software package (Douglas et al., 2019). This software was used to estimate the funtional profile from the16S rRNA gene obtained data and predict the metabolic-pathways and enzymes involved in nitrogen, sulfur, methane cycles and $\mathrm{CO}_{2}$ fixation. The predictions are given based on MetaCyc database (Karp et al., 2002) A heatmap was created to visualize the abundances of key enzymes using pheatmap package in $\mathrm{R}$.

Assembled genome Ga0077536 from metagenome, accessioned as LNEL00000000, was functionally annotated using Prodigal (Hyatt et al., 2010) for gene prediction, and Sma3s (Muñoz-Mérida et al., 2014) along with the curated Uniprot-SwissProt database (UniProt Consortium, 2019) for biological intepretation of genes.

\section{Results and Discussion}

\section{Microscopy}

FESEM images revealed abundant microbial cells in all the samples. Actinobacterial-like morphologies, similar to those reported by Riquelme et al. (2015a) in other volcanic caves, were observed in the mucous formation (MZ03-2B) (Fig. 3A, B). These microbial features comprise coccoid-shaped and filamentous cells with spiny surface ornamentations. Bacterial filaments with smooth surfaces were detected in the ochre stalactite (MZ03-3C), with less than 0.5-1 $\mu \mathrm{m}$ in diameter, probably of Actinobacteria (Fig. 3C). In addition, long hollow mineralized filaments were observed embedded in a glue-like matrix rich in Si (Fig. 3D). The mucous deposit with water runoff (MZ03-8H) showed less abundance of microbial structures. Interestingly, cells with long surface appendages were found in this sample (Fig. 3E), resembling the prosthecate bacterium found in grey vermiculation deposits, reported by D'Angeli et al. (2019) in Fetida Cave, an active sulfuric acid cave in Apulia, Italy. An intricate net of nano-scaled filaments with a collapsed microbial-like structure entrapped in the dense network was also observed in the mucous deposit with water runoff (MZ03-8H) (Fig. 3F). In contrast, microbial cells were abundantly observed in the moonmilk (MZ03-10J), comprising: i) an interwoven mass of filaments with less than $1 \mu \mathrm{m}$ in diameter (Fig. 3G), and ii) clusters of coccoid-shaped cells with smooth surfaces and approximately $1 \mu \mathrm{m}$ in diameter, which were embedded in extracellular polymeric substances (EPS) and spread all over the sample surface (Fig. 3H).

\section{Microbial community composition}

Alpha diversity metrics were assessed to know both diversity indices and richness estimators of bacterial community in the analyzed samples. On one hand, Simpson 1-D and Shannon-Weaver diversity indices were implemented to provide an insight of the community composition. Simpson 1-D index measures the relative abundance of species, where value of ranges varies between 0 and 1, with samples close to 0 when no diversity is observed and samples with values close to 1 when a high diversity is showed (Simpson, 1947). Shannon-Weaver index is focused 
198

199

200

201

202

203

204

205

206

207

208

209

210

211

212

213

214

215

216

217

218

219

220

221

222

223

224

225

226

227

228

229

230

231

232

233

234

235

236

237

on species richness and its value increases when the number of species also increases and the distribution of individuals among species becomes even (Lemos et al., 2011). On the other hand, richness estimators Chaol and ACE predict the number of species in the sample, focusing on the low abundance of rare species observed (Hughes et al., 2011). Thus, the mucous formation (MZ03-2B) was more diverse and even, whereas the moonmilk (MZ03-10J) showed the lowest diversity. Regarding ACE/Chaol estimators and the observed species, the mucous deposit with water runoff (MZ03-8H) showed the highest number of species, as would correspond to enrichment from the top soil (Table 1).

The Venn diagram of shared OTUs among the studied samples resulted in a higher significance between microbial communities from the ochre mucous formation (MZ03-2B) and the mucous deposit with water runoff (MZ03-8H), sharing 6809 OTUs representing the 32.51\% and $33 \%$, respectively (Supplemental Fig. 3). The mucous deposit with water runoff (MZ03-8H) and the ochre stalactite (MZ03-3C) shared the second biggest group of OTUs in common for this study (4021), entailing 19.26\% and 19.60\%, respectively. However, the ochre stalactite (MZ03$3 \mathrm{C}$ ) and the mucous deposit with water runoff (MZ03-2B) only shared $6.87 \%$ and $6.65 \%$ of their total OTUs, respectively. The ochre stalactite (MZ03-3C) showed the highest number of unique groups (52.12\%), followed by the moonmilk (MZ03-10J) (47.42\%), mucous formation (MZ032B) $(40.82 \%)$, and the mucous deposit with water runoff (MZ03-8H) (26.66\%). Thus, the ochre stalactite (MZ03-3C) was reported as the most exclusive of the analyzed samples, whereas the mucous deposit with water runoff $(\mathrm{MZ03}-8 \mathrm{H})$ pooled the majority of their OTUs with the other samples. All samples shared a total of 788 OTUs, being especially representative for the moonmilk (MZ03-10J), with almost $16.95 \%$ of the total OTUs in this sample.

\section{Microbial community structure}

A review on the weathering of volcanic (basaltic) rocks revealed that the process has been studied in terrestrial (Kelly et al., 2014) and marine environments (Gulmann et al., 2016). In terrestrial environments (soils) the major groups involved in biological weathering were Actinobacteria, Acidobacteria and Proteobacteria although their abundance varied with the environment and location (Gomez-Alvarez, King \& Nusslein, 2007). Similar phyla distributions were observed in lava tube caves (Riquelme et al., 2015b; Lavoie et al., 2017).

Fuente de la Canaria Cave is affected by the leaching of organic compounds and ashes through cracks and fissures of the volcanic rock (Fig. 2C) as well as the dripping waters from the ceiling. Obviously this must influence the microbial communities. The four samples collected in the cave show an almost exclusive dominance of Bacteria over Archaea and a negligible presence of unassigned prokaryotes (Table 2). Table 3 displays the distribution in phyla and reveals a majority abundance of Proteobacteria (range 89.4-37.6\%), followed by Actinobacteria (20.2-3.4\%), Acidobacteria (12.6-2.4\%) and Candidatus Rokubacteria (8.4-0.4\%). These four phyla comprise abundances between $95.8 \%$ (moonmilk) and $71.9 \%$ (mucous formation).

Comparing the phyla abundance in all the four samples (Table 3), three of them showed relatively similar phyla distribution and abundances regarding the most noticeable phyla 
238

239

240

241

242

243

244

245

246

247

248

249

250

251

252

253

254

255

256

257

258

259

260

261

262

263

264

265

266

267

268

269

270

271

272

273

274

275

276

277

(Proteobacteria, Actinobacteria, Acidobacteria and Candidatus Rokubacteria). However, the moonmilk formation, showed about $90 \%$ of abundance of Proteobacteria, with minority representation of the other three phyla.

The striking abundance of Proteobacteria is a common feature in lava tube caves from New Mexico, Hawai'i and Azores (Northup et al., 2011; Riquelme et al., 2015b). In addition, the Proteobacteria classes are well represented in caves all over the world (Saiz-Jimenez, 2015), but Gammaproteobacteria are predominant in show caves (e.g. Lascaux Cave, France) impacted by tourism or anthropic activities (Bastian, Alabouvette \& Saiz-Jimenez, 2009).

Phyla with abundances below $5 \%$ in any of the samples and in decreasing order of abundance were Chloroflexi, Gemmatimonadetes, Nitrospirae, Planctomycetes, Bacteroidetes, Candidatus Dadabacteria, GAL15, Verrucomicrobia and Patescibacteria. Other phyla with relative abundances $<1 \%$ were also retrieved.

At the class taxonomic level (Fig. 4), the heat-map revealed the dominance of Gammaproteobacteria over all other classes, followed by the phylum Actinobacteria. The relative abundance of the different classes of Proteobacteria varied from each sample. The moonmilk showed an abundance of Gammaproteobacteria 2 to 3 times higher than the other three samples. Alphaproteobacteria and Deltaproteobacteria were considerably less abundant. These variances are in agreement with the findings of Gomez-Alvarez, King \& Nusslein (2007) who suggested that differences in the local environment and elemental composition of the volcanic deposits themselves may control bacterial community composition.

Within the Actinobacteria phylum, the classes Acidimicrobiia, Actinobacteria and Nitriliruptoria were represented, but only Actinobacteria was dominant in all samples (13.5$7.2 \%$ ) except in the moonmilk with $2.8 \%$ of relative abundance. Acidimicrobiia ranged between 5.1 and $2.7 \%$ in three samples but was insignificant in the moonmilk (MZ03-10J) (0.2\%). Nitriliruptoria reached importance in the ochre stalactite with $3 \%$ of relative abundance. These three classes are well represented in other lava tube caves and limestone caves worldwide (Riquelme et al., 2015a; Saiz-Jimenez, 2015; Lavoie et al., 2017; Gonzalez-Pimentel et al., 2018).

The class NC10 of Candidatus Rokubacteria was the third group in abundance. In this group, methane oxidation under anaerobic conditions is associated with nitrite reduction (Lomakina et al., 2020) and the relative abundances were important in three samples, and lower in the ochre stalactite MZ03-3C.

The Acidobacteria classes identified in the samples from Fuente de la Canaria Cave comprise Acidobacteriia, Blastocatellia, Holophagae and subdivisions 6 and 17. Blastocatellia was the most abundant class among Acidobacteria, with relative abundances ranging from $4.1 \%$ to $1.4 \%$. Acidobacteriia and subdivision 17 ranged between $3.4 \%$ and $2.5 \%$ in the mucous formation and the mucous deposit with water runoff. A survey on different lava caves from La Palma Island provided evidence of the presence of Acidobacteria, but with relative abundances below 5\% (Gonzalez-Pimentel, 2019). Blastocatellia and subdivision 6 were abundant in Altamira Cave (Zimmermann et al., 2005) and in soil (Janssen, 2006) and were reported in coralloids from

Peer) reviewing PDF | (2021:02:58418:1:1:NEW 7 Apr 2021) 
278

279

280

281

282

283

284

285

286

287

288

289

290

291

292

293

294

295

296

297

298

299

300

301

302

303

304

305

306

307

308

309

310

311

312

313

314

315

316

317

another La Palma Island cave (Gonzalez-Pimentel et al., 2018). In addition, clones closely related to the genera Luteitalea and Vicinamibacter, from subdivision 6, were retrieved in lava tube caves from Galapagos Islands (Miller et al., 2020b).

The phyla with lower relative abundances, such as Chloroflexi, Gemmatimonadetes, Planctomycetes, Bacteroidetes, Nitrospirae and Verrucomicrobia are commonly found at low rates in lava tube caves (Northup et al., 2011; Riquelme et al., 2015b; Lavoie et al., 2017). Other less common phyla (GAL15, Candidatus Dadabacteria) are rarely found. GAL15 was recovered in Pindal Cave, Spain (unpublished results) and $\mathrm{Ca}$. Dadabacteria was observed in Nerja Cave, Spain (Jurado et al., 2020b).

Figure 5 shows the heat-map of the families and genera retrieved in the four samples from Fuente de la Canaria Cave. The class Gammaproteobacteria is composed of the orders Betaproteobacteriales, Ga0077536, Nitrosococcales, PLTA13 and Steroidobacterales.

The most abundant group belongs to an uncultured bacterium from the gammaproteobacterial order $\mathrm{Ga} 0077536$ with $70.5 \%$ of relative abundance in the moonmilk, and abundances ranging between 15.4 and $4.6 \%$ in the rest of samples. For the order Ga0077536 very short information is available. This lineage has been previously found associated with marine organisms such as corals (Silva-Lima et al., 2020). Functional analysis carried out on the genome assembled from a metagenomic sample (Pinto et al., 2015) resulted in the presence of genes likely involved in sulfur, nitrogen and carbon metabolism. Thus, from 1278 annotated genes, using Uniprot SwissProt database, out of 4368 totals predicted by Prodigal, 18 genes were related to pathways involved in nitrogen metabolism and 23 to nitrogen fixation, as well as 17 and 9 genes in onecarbon and sulfur metabolism, respectively. This bacterium depicted the whole gene cluster involved in the subpathway that synthesizes formate from formaldehyde [H(4)MPT route], which was formerly described in the methylotrophic bacterium Methylorubrum extorquens (Vorholt et al., 1998). Thus, the high representativeness of Ga0077536, especially in the moonmilk, could play a relevant role in the methane cycle.

Another outstanding group within the Gammaproteobacteria was the order Betaproteobacteriales which encompasses four families, B1-7BS, Burkholderiaceae, Nitrosomonadaceae and a family of uncultured bacterium. This last family was also relatively important in the mucous formation (9.4\%) and the mucous deposit with water runoff (5.2\%). In the other two samples the abundances were insignificant, below $0.2 \%$. Members of the family B1-7BS were previously retrieved from an Alpine cave (Jurado et al., 2020a) and from a sulfide mineral deposit in USA (Jones et al., 2017). In the family Burkholderiaceae was found the genus Polaromonas, with $2.6 \%$ in the mucous formation and $1.7 \%$ in the mucous deposit with water runoff.

In Fuente de la Canaria Cave, the family Nitrosomonadaceae comprises the genera IS-44 and MND1. IS-44 was previously found in soils (Zarraonaindia et al., 2015; Heo et al., 2020), and MND1 in caves and soils (Jones, Lyon \& Macalady, 2008; Rummel et al., 2020).

The order Nitrosococcales and family Nitrosococcaceae is signified by the genus wb1-P19, with abundances from $13.9 \%$ in the ochre stalactite to $1.1 \%$ in the moonmilk. This genus was the 
318 most abundant group in the vermiculations of an Alpine cave (Jurado et al., 2020a). Other 319 records at lower abundances include caves in different continents (Holmes et al., 2001; Zhu et

320

321

322

323

324

325

326

327

328

329

330

331

332

333

334

335

336

337

338

339

340

341

342

343

344

345

346

347

348

349

350

351

352

353

354

355

356 al., 2019; Anda et al., 2020).

Members of the order PLTA13, which attained some importance only in the ochre stalactite $(4.0 \%)$ and the mucous deposit with water runoff (1.7\%), have been described in soils (Rummel et al., 2020) and in a Swedish mine of rare earth elements (Sjöberg et al., 2017).

The genus Steroidobacter was identified within the order Steroidobacterales with about 10\% of relative abundance in the moonmilk. This genus was moderately common in limestone and volcanic caves (Porca et al., 2012; Riquelme et al., 2015b; Lavoie et al., 2017).

The order Rhizobiales (Alphaproteobacteria) included four families from which the Beijerinckiaceae with an uncultured bacterium had relative abundances around $2-3 \%$ in all the samples, except in the moonmilk with $0.3 \%$. The only identified genus was Hyphomicrobium, with relative abundances of $1.7 \%$ in the moonmilk and below $1 \%$ in the other samples.

The actinobacterial family Pseudonocardiaceae was represented by the genus Crossiella, with relative abundances above $12 \%$ in the ochre stalactite and $6 \%$ in the mucous formation and the mucous deposit with water runoff. In the moonmilk this genus was relatively minor, about $2.5 \%$ of abundance. Crossiella is a dominant member of the microbial communities of lava tube caves (Riquelme et al., 2015b; Spilde et al., 2016) and its moonmilk deposits (Miller et al., 2020b). The family Euzebyaceae only reached some importance in the ochre stalactite. Euzebyaceae was very abundant in microbial mats on coralloids from a lava tube cave of La Palma Island (Gonzalez-Pimentel et al., 2018) and Euzebyales was the second most abundant order (in number of sequences) in New Mexico and Hawai'i lava tube caves (Riquelme et al., 2015a).

The classes Acidimicrobiia and Actinobacteria contain uncultured bacteria. Metagenomic analyses have revealed that there were many uncultured actinobacterial species belonging to the class Acidimicrobiia in subterranean environments and acid mine drainage, in addition to freshwater and marine samples (Gonzalez-Pimentel, 2019).

Whitin the phylum Acidobacteria relative abundances above $2 \%$ only were found in the mucous formation and mucous deposit with water runoff for Acidobacteriia, and for the clade 11-24 in the ochre stalactite. Both 11-24 and RB41 clades, in addition to Steroidobacter and Nitrospira, all of them were retrieved in this study and identified as members of the rhizosphere bacterial community (Liu, Jin \& Guo, 2020). The uncultivated clade RB41 was very abundant in tundra soils (Ivanova et al., 2020). These findings are in agreement with the presence of roots in the shallow cave ceiling.

The genus Nitrospira, within the family Nitrospiraceae, as well as Candidatus Methylomirabilis (Rokubacteria) attained abundances over $2 \%$ in most samples. Nitrospira comprises ammonia-oxidizing bacteria which are relatively common in caves (Tomczyk-Żak \& Zielenkiewicz, 2016). Nitrospira was previously found in volcanic caves from California, New Mexico, Hawai'i and Azores (Northup et al., 2011; Riquelme et al., 2015b; Lavoie et al., 2017). Candidatus Methylomirabilis is a denitrifying methanotroph (Wu et al., 2012). The clade wb1- 
357

358

359

360

361

362

363

364

365

366

367

368

369

370

371

372

373

374

375

376

377

378

379

380

381

382

383

384

385

386

387

388

389

390

391

392

393

394

395

396

A12 was retrieved from an Australian cave (Holmes et al., 2001). Therefore, it appears that nitrifiers are widespread in the cave.

Gemmatimonadetes are relatively common in lava tube caves and limestone caves (Northup et al., 2011; Saiz-Jimenez, 2015). DeBruyn et al. (2011) reported that bacteria belonging to the phylum Gemmatimonadetes comprise approximately $2 \%$ of soil bacterial communities, have a generalist ecological strategy and adapt to a variety of environments. Gemmatimonadaceae were well represented (around 5\%) in the mucous formation and the mucous deposit with water runoff.

In Fuente de la Canaria Cave Planctomycetacia members were affiliated with the family Gemmataceae, and Bacteroidetes with the order Kryptoniales (family BSV26), both with low relative abundances. This last family has been retrieved from shallow groundwater aquifer in southeastern Wisconsin (Gayner, 2018) and from Florida lagoon sediments (Bradshaw, 2020).

Candidatus Rokubacteria, Gemmatimonadetes, Candidatus Dadabacteria, Patescibacteria, Verrucomicrobia, Candidatus GAL15, and some others phyla are part of a so-called rare cave biosphere (Hershey \& Barton, 2018). Most of these phyla have been retrieved from soils and subsurface soils (Hug et al., 2016; Zeng et al., 2016; Brewer et al., 2019; Nixon et al., 2019; Lemos et al., 2020; Sharrar et al., 2020).

It must be noticed the close similarity in taxa and relative abundances of both mucous samples of ochre color (MZ03-2B and MZ03-8H), although the last was located on a rock crack with water runoff. The sample MZ03-10J, with abundant moonmilk deposits, very different from the others, represented a niche almost completely dominated by Proteobacteria.

Regarding the participation of the bacteria in the geochemical cycle of elements, some insights can be derived from the taxonomical groups retrieved in Fuente de la Canaria Cave. The ecological functions of the bacterial communities were analyzed by FAPROTAX (Fig. 6). A total of 54 microbial functional groups corresponding to $19 \%$ of OTUs were identified. Within the identified OTUs we found a high proportion assigned to aerobic chemoheterotrophy, nitrification and methanotrophy across all the samples.

The major predicted ecological function was chemoheterotrophy, in which were involved the phyla Proteobacteria (Alpha- and Gammaproteobacteria) and Actinobacteria. Crossiella was the most representative genera in this function, in addition to other numerous genera, with lower relative abundance.

Microbial community functional profiles of samples collected in Fuente de la Canaria Cave were also predicted using PICRUSt2 software. In this study we focused on the enzymes involved in methane, sulfur, nitrogen metabolism and $\mathrm{CO}_{2}$ fixation (Fig. 7).

The predictive accuracy of PICRUSt2 was evaluated by the weighted Nearest Sequenced Taxon Index (NSTI score), which reflects how similar are the microorganisms in a given sample when comparing with available reference genomes. According to developers, PICRUSt produces accurate metagenome predictions with a mean NSTI of 0.17 . The mean NSTI score of the sequences was 0.20 for the ochre stalactite and 0.21 for the other three samples, close to those reported for other environmental recent studies with higher mean NSTI values (Martin-Pozas et 
397

398

399

400

401

402

403

404

405

406

407

408

409

410

411

412

413

414

415

416

417

418

419

420

421

422

423

424

425

426

427

428

429

430

431

432

433

434

435

436

al., 2020). The unexplored diversity in complex environmental communities was the main cause of the lower observed degree of accuracy and the results should be treated with caution. However the predictions could still provide some important insights into the microbial ecological functions of underexplored environments such as lava tube caves.

\section{Methane metabolism}

Two genera from Fuente de la Canaria Cave were involved in methylotrophy, Candidatus Methylomirabilis, a denitrifying methanotroph (Wu et al., 2012) and the genus Hyphomicrobium that can grow with low concentrations of $\mathrm{Cl}$ compounds such as methanol, methylamine, and others (Oren \& Xu, 2014). However, Hyphomicrobium was not confirmed by FAPROTAX. Other possible methanotrophic bacteria have been identified within the family Beijerinckiaceae. This family comprises obligate methanotrophs and examples of the intermediate states: facultative methylotrophs and facultative methanotrophs, in addition to chemoorganoheterotrophs. This metabolic trait was confirmed by FAPROTAX (Fig. 6). The functional profiles of the ochre deposit samples (MZ03-2B and MZ03-8H) with respect to the stalactite and moonmilk samples (MZ03-3C and MZ03-10J) presented an increasing level of methanotrophy, methylotrophy and hydrocarbon degradation functional groups which were associated with the families Beijerinckiaceae, Methylococcaceae and Methylomirabilaceae (Fig. 5). A deeper analysis of key methane metabolism enzymes (Fig. 7) revealed an increase of the particulate methane monoxygenase in the three ochre samples, which is mainly associated with the family Beijerinckiaceae. In addition, PICRUSt2 metabolic predictions revealed Hyphomicrobium, MND1 and IS-44 and Nitrospira encoded enzymes with the potential to support catabolic methane or ammonia oxidation, as genes encoding particulate methane monooxygenase and ammonia monooxygenase share high sequence identity (Holmes et al., 1995). In general, the genes related to methane metabolism presented a low abundance in the moonmilk. This could be due to the absence of metabolic information on Ga0077536 bacterium in PICRUSt 2 database, since gene prediction and annotation analysis on the genome resulted in the identification of the putative dehydrogenase XoxF (EC: 1.1.2.7), the formylmethanofuran-tetrahydromethanopterin formyltransferase (EC: 2.3.1.101), the 5,6,7,8-tetrahydromethanopterin hydro-lyase (E.C: 4.2.1.147), the methenyltetrahydromethanopterin cyclohydrolase (E.C: 3.5.4.27), the aralkylamine dehydrogenase light chain (E.C: 1.4.9.1), all these enzymes found unequally in the analyzed samples. Beyond these proteins, the presence of putative glutathionedependent formaldehyde-activating enzyme (E.C: 4.4.1.22) was observed in this bacterium, but not in the rest of bacteria.

A metagenomic study of the gammaproteobacterial Ga0077536 showed the putative presence of glutathione-dependent formaldehyde-activating gene, which is related to methane metabolism. For methylotrophic bacteria, formaldehyde is also a central intermediate for oxidizing methanol or methylamine (Simon et al., 2017).

There is previous evidence of microbial methane oxidation in caves. Fernandez-Cortes et al. (2015) investigated methane consumption in several Spanish caves and showed the presence of 
437 Methylocapsa aurea, Methylomicrobium album, Methylococcus capsulatus and K1-1 and K3-16 438 methanotrophs in well-ventilated caves. Webster et al. (2018) studied 42 sediment samples from 43921 caves in North America and found methanotrophs in $88 \%$ of the samples. Pratscher et al.

440 (2018) reported the presence of microbial groups containing the upland soil cluster $\alpha$, responsible 441 for most of the methane uptake, in volcanic soils and in volcanic cave wall biofilms all over the 442 world. Martin-Pozas et al. (2020) reviewed the role of methane-oxidizing bacteria in caves. 443 These bacteria not only consume large amounts of the methane that enters to the underground 444 atmosphere but also produce bioactive compounds, such as methanobactins, with potential 445 application in medicine.

446

447

448

449

450

451

452

453

454

455

456

457

458

459

460

461

462

463

464

465

466

467

468

469

470

471

472

473

474

475

476

\section{Sulfur metabolism}

Proteobacteria contains sulfur oxidizing and reducing lineages. In fact, Fig. 6 shows evidence of sulfur and sulfate respiration and in the moonmilk was associated to the order Ga0077536 (Supplemental Table 2). In particular, the genes cysI and cysJ, known to be involved in the subpathway that synthesizes hydrogen sulfide from sulfite (NADPH route), were predicted as alpha and beta subunits of sulfite reductase activity.

\section{$\mathrm{CO}_{2}$ fixation}

The gene families related to $\mathrm{CO}_{2}$ fixation were represented across all samples. The most abundant $\mathrm{CO}_{2}$ fixation pathways predicted by PICRUSt2 were Calvin-Benson-Bassham (CBB) cycle and the reductive tricarboxylic acid (TCA) cycle. As many enzymes involved in these pathways are involved in other multiple pathways, we examined the presence of key enzymes of the known autotrophic $\mathrm{CO}_{2}$ fixation pathways. Ribulose-biphosphate carboxylase/oxygenase (RubisCo), responsible for $\mathrm{CO}_{2}$ fixation, is the key enzyme of the $\mathrm{CBB}$ cycle, which is not only extensive to phototrophic environments but has been described in chemoautotrophic

proteobacteria that perform 'dark' $\mathrm{CO}_{2}$ fixation in diverse habitats (Tsai et al., 2015). The phosphoribulokinase (prkB) enzyme rarely occurs in organisms that lack the CBB cycle (Frolov et al., 2019). Both enzymes were mainly predicted in the family Nitrosomonadaceae, some uncultured members from the gammaproteobacterial order Ga0077536, and the genera Hyphomicrobium and Polaromonas (Supplemental Table 3). Most of the enzymes of the TCA cycle could catalyze both directions, but the enzymes that catalyzed the reductive direction (ATP citrate lyase, 2-oxoglutarate:ferredoxin oxidoreductase, pyruvate:ferredoxin oxidoreductase and fumarate reductase) were only associated with the genus Nitrospira. No other $\mathrm{CO}_{2}$ fixation pathways, such as the reductive acetyl coenzyme A pathway, and the 3-hydroxypropionate cycle, could be found in PICRUSt2; however, it is important to emphasize the identification of the subunits alpha and beta of the acetyl-coenzyme A carboxylase carboxyl transferase (E.C: 2.1.3.15) in $\mathrm{Ga} 0077536$ bacterium, since these enzymes could be relevant in $\mathrm{CO}_{2}$ fixation process in prokaryotes (Hügler et al., 2003). First, biotin carboxylase (E.C: 6.3.4.14) catalyzes the carboxylation of biotin on its carrier protein (BCCP) and then the $\mathrm{CO}_{2}$ group is transferred by the carboxyl transferase to acetyl-CoA to form malonyl-CoA. To summarize, 
477 gammaproteobacterial order Ga0077536 was very abundant in moonmilk deposits and likely

478 involved in calcite deposition.

479

480

481

Nitrogen metabolism

482

The nitrogen cycle is represented by the family Nitrosomonadaceae, all of whose cultivated

483 representatives are lithoautotrophic ammonia oxidizers (Prosser, Head \& Stein, 2014) and the

484 genus Nitrospira composed of ubiquitous nitrite-oxidizing bacteria (Koch et al., 2015). Indeed, nitrogen fixation is a remarkable trait of the family Beijerinckiaceae (Marin \& Arahal, 2014) and several members of the family Burkholderiaceae (Coenye, 2014). This allows these microorganisms to thrive in niches of scarce nitrogen availability, as in some oligotrophic caves. FAPROTAX assigned high relative abundances to aerobic ammonia oxidation (Nitrosomonadaceae and Candidatus Nitrososphaera) and aerobic nitrite oxidation (Nitrospira, Leptospirillum and Nitrosomonadaceae). This metabolic trait was also predicted by PICRUSt 2. Relatively lower were other nitrogen-related activities, such as denitrification, nitrate respiration, nitrate reduction, or nitrogen respiration.

Interestingly, the abundance of the enzymes hydroxylamine reductase and nitrogenase was high in the ochre stalactite, followed by the moonmilk (Supplemental Table 4). The first enzyme

495

496

497

498

499

500

501

502

503

504

505

506

507

508

509

510

511

512

513

514

515

516 was mainly related to an uncultured bacterium from Ga0077536. However the presence of the enzyme nitrogenase was predicted for uncultured members from Beijerinckiaceae, an uncultured bacterium from Ga0077536, and uncultured members of the genus Crossiella. The results suggested that white precipitations and ochre biofilms might be important sites for nitrogen cycling in caves, particularly nitrogen fixation.

Of interest is the abundance of the enzyme urease in the moonmilk, also present in the rest of samples, with lower relative abundance. PICRUSt 2 analyses reported that urease activity in the moonmilk was associated to an uncultured bacterium from the order Ga0077536. On the contrary, in the other samples, the urease activity was related to the presence of Crossiella and uncultured members within the family Beijerinckiaceae (Supplemental Table 4).

The ochre stalactite was characterized by large quantities of Crossiella; this genus is a common dweller of lava tube caves of Hawai'i and Azores (Riquelme et al., 2015; Spilde et al., 2016) and also in limestone caves (Wiseschart et al., 2019), although at lower abundances than in lava tube caves. Gonzalez-Pimentel (2019) found an extraordinary abundance of Crossiella in moonmilk from La Palma lava tube caves.

Cuezva et al. (2020) reported that Crossiella found in moonmilk have the ability to capture $\mathrm{CO}_{2}$ from the underground atmosphere, resulting in precipitation of calcium carbonate as a byproduct of the action of carbonic anhydrase. Sanchez-Moral et al. (2012) reported that in the early stages of moonmilk deposition bacteria induces carbonate precipitation, but subsequently a microbial deactivation occurs when carbonate accumulates.

For Li et al. (2018) Crossiella, likely the primary cause of $\mathrm{CaCO}_{3}$ precipitation, was the dominant genus (about $84 \%$ of relative abundance) in a sample of white stains collected from the surface of a statue inside a Chinese cave. This sample presented aggregates of microorganisms 
517 and inorganic minerals and the analysis by SEM-EDS revealed that the stains were mostly 518 composed of calcium carbonate.

519 From the review of all available literature it becomes clear that Crossiella is a common 520 inhabitant of caves and colonizes moonmilk deposits, where it must have an important role in 521 calcite precipitation.

522 Crossiella is able to hydrolyze or decompose urea (Franco \& Labeda, 2014). Ureolytic 523 bacteria are associated with high rates of calcium carbonate precipitation in alkaline 524 environments rich in $\mathrm{Ca}^{2+}$ ions, such as caves. Several authors have reported calcium carbonate 525 precipitation by ureolytic bacteria from caves (Omoregie, Ong \& Nissom, 2018; Enyedi et al., 526 2020). This strongly suggests a principal role of Crossiella in microbially-induced carbonate

527

528

529

530

531

532

533

534

535

536

537

538

539

540

541

542

543

544

545

546

547

548

549

550

551

552

553

554

555

556 precipitation (MICP) in caves, and particularly in moonmilk deposits.

However, not only ureolysis is involved in MICP. A few authors reported that other five metabolic pathways can induce this precipitation: photosynthesis, ammonification, denitrification, sulfate reduction, and methane oxidation (Zhu \& Dittrich, 2016; Omoregie, Ong \& Nissom, 2018). Most of these processes were predicted by FAPROTAX in Fuente de la Canaria Cave. Moreover, cell walls and extracellular polymeric substances can serve as templates for carbonate precipitation (Enyedi et al., 2020).

\section{Other elements}

Other mineral elements in the volcanic rock from Fuente de la Canaria Cave are iron and manganese (Carracedo et al., 2001). With abundances below 2\% were identified two genera: Hyphomicrobium and Polaromonas. Hyphomicrobium, a prosthecate bacterium (Oren \& Xu, 2014) (Fig. 2E), is relatively frequent in cave ferromanganese deposits (Northup et al., 2003; Spilde et al., 2006). This genus is known to mediate the oxidation and precipitation of manganese and iron in different environments (Ghiorse \& Ehrlich, 1992). The genus Hyphomicrobium and the lineage wb1-A12 were also related with manganese nodules (Molari et al., 2020). Polaromonas was found in manganese deposits from an Italian cave (Vaccarelli et al., 2021).

\section{Conclusions}

Different types of speleothems and colored microbial mats, from Fuente de la Canaria Cave, a representative lava tube cave, in La Palma Island, Spain, were studied using DNA nextgeneration sequencing.

The distribution in phyla revealed a majority abundance of Proteobacteria, followed by Actinobacteria, Acidobacteria and Candidatus Rokubacteria. These four phyla comprised a total relative abundance of $72-96 \%$. The main ecological functions were chemoheterotrophy, methanotrophy, sulfur and nitrogen metabolisms and $\mathrm{CO}_{2}$ fixation; although a wide diversity of other ecological functions was outlined. The abundant presence of lineage Ga0077536, in an extensive area coated by moonmilk, points to a further research in Fuente de la Canaria Cave aiming at the isolation of this bacterium. 
557

558

559

560

561

562

563

564

565

566

567

568

569

570

571

572

573

574

575

576

577

578

579

580

581

582

583

584

585

586

587

588

589

590

591

592

593

594

595

596

The detection of several putative lineages associated with C, N, S, Fe and Mn cycling indicated that Fuente de la Canaria Cave basalt surfaces were colonized by metabolically diverse prokaryotic communities involved in the biogeochemical cycling of major elements.

The microbial communities of lava tube caves from the volcanic Canarian, Azorean and Hawaiian Islands are comparatively similar regarding the distribution of major phyla. Although different geographical locations and environmental conditions can contribute to the diversity and abundance of minor phyla, the data suggest that the volcanic rocks largely determine the distribution of the microbial communities of lava tube caves. This distribution is also governed by natural and/or anthropogenic conditions of the overlying surface layers.

\section{References}

Anda D, Szabó A, Kovács-Bodor P, Makk J, Felföldi T,Ács E, Mádl-Szönyi J, Borsodi AK. 2020. In situ modelling of biofilm formation in a hydrothermal spring cave. Scientific Reports 10:21733. DOI:10.1038/s41598-020-78759-4.

Bastian F, Alabouvette C, Saiz-Jimenez C. 2009. Bacteria and free-living amoeba in Lascaux Cave. Research in Microbiology 160: 38-40. DOI:10.1016/j.resmic.2008.10.001.

Beier C, Haase KM, Brandl PA. 2018. Melting and mantle sources in the Azores. In: Kueppers U, Beier C, eds. Volcanoes of the Azores: Revealing the Geological Secrets of the Central Northern Atlantic Islands. Heidelberg: Springer, 251-280.

Bolger AM, Lohse M, Usadel B. 2014. Trimmomatic: a flexible trimmer for Illumina sequence data. Bioinformatics 30: 2114-2120. DOI:10.1093/bioinformatics/btu170.

Bradshaw DJ. 2020. Effects of natural and anthropogenic impacts on the microbiome of the Indian River Lagoon, Fl, USA. D. Phil. Thesis, Florida Atlantic University, Boca Raton.

Brewer TE, Aronson EL, Arogyaswamy K, Billings SA, Botthoff JK, Campbell AN, Dove NC, Fairbanks D, Gallery RE, Hart SC, Kaye J, King G, Logan G, Lohse KA, Maltz MR, Mayorga E, O'Neill C, Owens SM, Packman A, Pett-Ridge J, Plante AF, Richter DD, Silver WL, Yang WH, Fierer N. 2019. Ecological and genomic attributes of novel bacterial taxa that thrive in subsurface soil horizons. mBio 10:e1318-19.

DOI:10.1128/mBio.01318-19.

Caporaso JG, Kuczynski J, Stombaugh J, Bittinger K, Bushman FD, Costello EK, Fierer N, Gonzalez Peña, A, Goodrich JK, Gordon, JI, Huttley, GA, Kelley ST, Knights D, Koenig JE, Ley RE, Lozupone CA, McDonald, D, Muegge, BD, Pirrung M, Reeder J, Sevinsky JR, Turnbaugh, PJ, Walters WA, Widmann J, Yatsunenko T, Zaneveld J, Knight R. 2010. QIIME allows analysis of high-throughput community sequencing data. Nature Methods 7: 335-336. DOI:10.1038/NMETH.F.303.

Carracedo JC, Troll VR. 2016. The Geology of the Canary Islands. Amsterdam: Elsevier. DOI:10.1016/B978-0-12-809663-5.00001-3.

Carracedo JC, Badiola ER, Guillou H, de la Nuez J, Pérez Torrado F.J. 2001. Geology and volcanology of La Palma and El Hierro, Western Canaries. Estudios Geológicos 57: 175273. 
597

598

599

600

601

602

603

604

605

606

607

608

609

610

611

612

613

614

615

616

617

618

619

620

621

622

623

624

625

626

627

628

629

630

631

632

633

634

635

636

Casalbore D, Romagnoli C, Pimentel A, Quartau R, Casas D, Ercilla G, Hipólito A, Sposato A, Chiocci FL. 2015. Volcanic, tectonic and mass-wasting processes offshore Terceira Island (Azores) revealed by high-resolution seafloor mapping. Bulletin of Volcanology 77: 24. DOI:10.1007/s00445-015-0905-3.

Coenye T. 2014. The family Burkholderiaceae. In: Rosenberg E, DeLong EF, Lory S, Stackebrandt E, Thompson F, eds, The Prokaryotes. Alphaproteobacteria and Betaproteobacteria, Berlin: Springer-Verlag, 758-776. DOI 10.1007/978-3-642-30197-1. Cuezva S, Martin-Pozas T, Fernandez-Cortes A, Cañaveras JC, Janssens I, Sanchez-Moral S. 2020. On the role of cave-soil in the carbon cycle. A first approach. 22nd EGU General Assembly, Abstract EGU-21793.

https://ui.adsabs.harvard.edu/abs/2020EGUGA..2221793C.

D'Angeli IM, Ghezzi D, Leuko S, Firrincieli A, Parise M, Fiorucci A, Vigna B, Addesso R, Baldantoni D, Carbone C, Miller AZ, Jurado V, Saiz-Jimenez C, De Waele J, Cappelletti M. 2019. Geomicrobiology of a seawater-influenced active sulfuric acid cave. PLOS One 14: e0220706. DOI:10.1371/journal.pone.0220706.

De los Ríos A, Bustillo MA, Ascaso C, Carvalho MR. 2011. Bioconstructions in ochre speleothems from lava tubes on Terceira Island (Azores). Sedimentary Geology 236: 117 128. DOI:10.1016/j.sedgeo.2010.12.012.

DeBruyn JM, Nixon LT, Fawaz MN, Johnson AM, Radosevich M. 2011. Global biogeography and quantitative seasonal dynamics of Gemmatimonadetes in soil. Applied and Environmental Microbiology 77: 6295-6300. DOI:10.1128/AEM.05005-11.

Douglas GM, Maffei VJ, Zaneveld J, Yurgel SN, Brown JR, Taylor CM, Huttenhower C, Langille MGI. 2019. PICRUSt2: An improved and extensible approach for metagenome inference. BioRxiv preprint. DOI:10.1101/672295.

Dumpiérrez F, Fernández MI, Fernández O, García R, González AJ, Govantes F, Mata M, Muñoz M. 1997. Las cavidades volcánicas de la Villa de Mazo (La Palma, Islas Canarias). Vulcania 1: 1-48.

Edgar RC. 2010. Search and clustering orders of magnitude faster than BLAST. Bioinformatics 26: 2460-2461. DOI:10.1093.bioinformatics/btq461.

Enyedi NT, Makk J, Kótai L, Berényi B, Klébert S, Sebestyén Z, Molnár Z, Borsodi AK, LeélÖssy S, Demény A, Németh P. 2020. Cave bacteria-induced amorphous calcium carbonate formation. Scientific Reports 10: 8696. DOI:10.1038/s41598-020-65667-w.

Fernandez-Cortes, A.; Cuezva, S.; Alvarez-Gallego, M.; Garcia-Anton, E.; Pla, C.; Benavente, D.; Jurado, V.; Saiz-Jimenez, C.; Sanchez-Moral, S. 2015. Subterranean atmospheres may act as daily methane sinks. Nature Communications 6: 7003. DOI:10.1038/ncomms8003.

Fernández Lorenzo O. 2007. Avance global del catálogo de cavidades de La Palma (II). (Islas Canarias). Vulcania 8: 79-86.

Franco CMM, Labeda DP. 2014. The order Pseudonocardiales. In: Rosenberg E, DeLong EF, Lory S, Stackebrandt E, Thompson F. eds. The Prokaryotes. Actinobacteria. Heidelberg: Springer, 743-860. DOI:10.1007/978-3-642-30138-4. 
637

638

639

640

641

642

643

644

645

646

647

648

649

650

651

652

653

654

655

656

657

658

659

660

661

662

663

664

665

666

667

668

669

670

671

672

673

674

675

676

Frolov EN, Kublanov IV, Toshchakov SV, Lunev EA, Pimenov NV, Bonch-Osmolovskaya EA, Lebedinsky AV, Chernyh NA. 2019. Form III RubisCO-mediated transaldolase variant of the Calvin cycle in a chemolithoautotrophic bacterium. Proceedings of the National Academy of Sciences of the United States of America 116: 18638-18646. DOI:10.1073/pnas.1904225116.

Gayner NJ. 2018. River bank inducement influence on a shallow groundwater microbial community and its effects on aquifer reactivity. D. Phil. Thesis, Milwaukee: University of Wisconsin. https://dc.uwm.edu/etd/1990.

Ghiorse WC, Hirsch P. 1979. An ultrastructural study of iron and manganese deposition associated with extracellular polymers of Pedomicrobium-like budding bacteria. Archives of Microbiology 123: 213-226.

Gomez-Alvarez V, King GM, Nüsslein K. 2007. Comparative bacterial diversity in recent Hawaiian volcanic deposits of different ages. FEMS Microbiology Ecology 60: 60-73. DOI:10.1111/j.1574-6941.2006.00253.x

Gonzalez-Pimentel JL. 2019. Microorganismos de las cuevas volcánicas de La Palma (Islas Canarias). Diversidad y potencial uso biotecnológico. D. Phil. Thesis, Sevilla: University Pablo de Olavide. https://digital.csic.es/handle/10261/185148.

Gonzalez-Pimentel JL, Miller AZ, Jurado V, Laiz L, Pereira MFC, Saiz-Jimenez C. 2018. Yellow coloured mats from lava tubes of La Palma (Canary Islands, Spain) are dominated by metabolically active actinobacteria. Scientific Reports 8: 1944. DOI:10.1038/s41598018-20393-2.

Gulmann LK, Beaulieu SE, Shank TM, Ding K, Seyfried WE, Sievert SM. 2015. Bacterial diversity and successional patterns during biofilm formation on freshly exposed basalt surfaces at diffuse-flow deep-sea vents. Frontiers in Microbiology 6: 901. DOI:10.3389/fmicb.2015.00901.

Hathaway JJM, Garcia MG, Balasch MM, Spilde MM, Stone FD, Dapkevicius MDLNE, Amorim IR, Gabriel R, Borges PAV, Northup DE. 2014a. Comparison of bacterial diversity in Azorean and Hawai'ian lava cave microbial mats. Geomicrobiology Journal 31: 205-220. DOI:10.1080/01490451.2013.777491.

Hathaway JJM, Sinsabaug, R.L, Dapkevicius MDLNE, Northup DE. 2014b. Diversity of ammonia oxidation (amoA) and nitrogen fixation ( $n$ ifH) genes in lava caves of Terceira, Azores, Portugal. Geomicrobiology Journal 31: 221-235.

DOI:10.1080/01490451.2012.752424.

Heo YM, Lee H, Kwon SL, Yoo Y, Kim D, Han S-I, Lee AH, Kim C, Kim G-H, Kim J-J. 2020. Influence of tree vegetation on soil microbial communities in temperate forests and their potential as a proactive indicator of vegetation shift due to climate change.

Sustainability 12: 10591. DOI: 10.3390/su122410591.

Hershey OS, Barton HA. 2018. The microbial diversity of caves. In: Moldovan OT, Kovác, L, Hals, S. eds. Cave Ecology. Cham: Springer Nature Switzerland, 69-90. DOI:10.1007/9783-319-98852-8.

Peer) reviewing PDF | (2021:02:58418:1:1:NEW 7 Apr 2021) 
677

678

679

680

681

682

683

684

685

686

687

688

689

690

691

692

693

694

695

696

697

698

699

700

701

702

703

704

705

706

707

708

709

710

711

712

713

714

715

716
Holmes AJ, Costello A, Lidstrom ME, Murrell JC. 1995. Evidence that particulate methane monooxygenase and ammonia monooxygenase may be evolutionarily related. FEMS Microbiology Letters 132: 203-208.

Holmes AJ, Tujula NA, Holley M, Contos A, James JM, Rogers P, Gillings MR. 2001. Phylogenetic structure of unusual aquatic microbial formations in Nullarbor caves, Australia. Environmental Microbiology 3: 256-264. DOI:10.1046/j.14622920.2001.00187.x.

Hug LA, Thomas BC, Sharon I, Brown CT, Sharma R, Hettich RL, Wilkins MJ, Williams KH, Singh A, Banfield JF. 2016. Critical biogeochemical functions in the subsurface are associated with bacteria from new phyla and little studied lineages. Environmental Microbiology 18: 159-173. DOI:10.1111/1462-2920.12930.

Hughes JB, Hellmann JJ, Ricketts TH, Bohannan BJ. 2001. Counting the uncountable: statistical approaches to estimating microbial diversity. Applied and Environmental Microbiology 67: 4399-4406. DOI:10.1128/AEM.67.10.4399-4406.2001.

Hyatt D, Chen GL, Locascio PF, Land ML, Larimer FW, Hauser LJ. 2010. Prodigal: Prokaryotic gene recognition and translation initiation site identification. $B M C$ Bioinformatics 11: 119. DOI:10.1186/1471-2105-11-119.

Ivanova AA, Zhelezova AD, Chernov TI, Dedysh SN. 2020. Linking ecology and systematics of acidobacteria: Distinct habitat preferences of the Acidobacteriia and Blastocatellia in tundra soils. PLOS One 15: e0230157. DOI:10.1371/journal.pone.0230157

Janssen PH. 2006. Identifying the dominant soil bacterial taxa in libraries of 16S rRNA and 16S rRNA genes. Applied and Environmental Microbiology 72: 1719-1728. DOI: 10.1128/AEM.72.3.1719-1728.2006.

Jones DS, Lapakko KA, Wenz ZJ, Olson MC, Roepke EW, Sadowsky MJ, Novak PJ, Bailey JV. 2017. Novel microbial assemblages dominate weathered sulfidebearing rock from copper-nickel deposits in the Duluth Complex, Minnesota, USA. Applied and Environmental Microbiology 83:e00909-17. DOI:10.1128/AEM.00909-17.

Jones, D.S., Lyon, E.H., and Macalady, J.L. 2008. Geomicrobiology of biovermiculations from the Frasassi cave system. Journal of Cave and Karst Studies 70: 78-93.

Jurado V, Gonzalez-Pimentel JL, Miller AZ, Hermosin B, D’Angeli IM, Tognini P, De Waele J, Saiz-Jimenez C. 2020a. Microbial communities in vermiculation deposits from an Alpine cave. Frontiers in Earth Sciences 8: 586248. DOI: 10.3389/feart.2020.586248.

Jurado V, del Rosal Y, Gonzalez-Pimentel JL, Hermosin B, Saiz-Jimenez C. 2020b. Biological control of phototrophic biofilms in a show cave: The case of Nerja Cave. Applied Sciences 10: 3448. DOI:10.3390/app10103448.

Karp PD, Riley M, Paley SM, Pellegrini-Toole A. 2002. The MetaCyc Database. Nucleic Acids Research 30: 59-61.

Kelly LC, Cockell CS, Thorsteinsson T, Marteinsson V, Stevenson J. 2014. Pioneer microbial communities of the Fimmvörðuháls lava flow, Eyjafjallajökull, Iceland. Microbial Ecology 68: 504-518. DOI:10.1007/s00248-014-0432-3. 
717

718

719

720

721

722

723

724

725

726

727

728

729

730

731

732

733

734

735

736

737

738

739

740

741

742

743

744

745

746

747

748

749

750

751

752

753

754

755

Klügel A, Hansteen TH, Galipp K. 2005. Magma storage and underplating beneath Cumbre Vieja volcano, La Palma (Canary Islands). Earth and Planetary Sciences Letters 236: 211 226. DOI:10.1016/j.eps1.2005.04.006.

Koch H, Lücker S, Albertsen M, Kitzinger K, Herbold C, Spieck E, Nielsen PH, Wagner M, Daims H. 2015. Expanded metabolic versatility of ubiquitous nitrite-oxidizing bacteria from the genus Nitrospira. Proceedings of the National Academy of Sciences of the United States of America 112:11371-11376. DOI/10.1073/pnas.1506533112.

Hügler M, Krieger RS, Jahn M, Fuchs G. 2003. Characterization of acetyl-CoA/propionyl-CoA carboxylase in Metallosphaera sedula. Carboxylating enzyme in the 3-hydroxypropionate cycle for autotrophic carbon fixation. European Journal of Biochemistry 270: 736-744. DOI:10.1046/j.1432-1033.2003.03434.x.

Lambert, S., Tragin, M., Lozano, J-C., Ghiglione, J-F., Vaulot, D., Bouget, F-Y., and Galand, P.E. 2019. Rhythmicity of coastal marine picoeukaryotes, bacteria and archaea despite irregular environmental perturbations. The ISME J 13: 388-401. DOI:10.1038/s41396-0180281-z.

Lavoie KH, Winter AS, Read KJH, Hughes EM, Spilde MN, Northup DE. 2017. Comparison of bacterial communities from lava cave microbial mats to overlying surface soils from Lava Beds National Monument, USA. PLOS One 12: e0169339.

DOI:10.1371/journal.pone.0169339.

Lemos LN, Fulthorpe RR, Triplett EW, Roesch LF. 2011. Rethinking microbial diversity analysis in the high throughput sequencing era. Journal of Microbiological Methods 86: 42-51. DOI:10.1016/j.mimet.2011.03.014.

Lemos LN, Manoharan L, Mendes LW, Venturini AM, Pylro VS, Tsai SM. 2020. Metagenome assembled-genomes reveal similar functional profiles of CPR/Patescibacteria phyla in soils. Environmental Microbiology Reports 12: 651-655. DOI:10.1111/1758-2229.12880.

Li Q, Zhang B, Yang X, Ge Q. 2018. Deterioration-associated microbiome of stone monuments: structure, variation, and assembly. Applied and Environmental Microbiology 84: e02680-17. DOI.org/10.1128/AEM.02680-17.

Liu L, Jin L, Guo Q. 2020. Effects of soil microbiomes and enzymatic activities on Glechoma longituba. Hortscience 55: 515-521. DOI:10.21273/HORTSCI14659-19.

Lomakina A, Pogodaeva T, Kalmychkov G, Chernitsyna S, Zemskaya T. 2020. Diversity of NC10 bacteria and ANME-2d archaea in sediments of fault zones at Lake Baikal. Diversity 12: 10. DOI:10.3390/d12010010.

Louca S, Parfrey LW, Doebeli M. 2016. Decoupling function and taxonomy in the global ocean microbiome. Science 353: 1272-1277. DOI:10.1126/science.aaf4507.

Luis-Vargas MN, López-Martínez RA, Vilchis-Nestor AR, Daza R, Alcántara-Hernández RJ. 2019. Bacterial insights into the formation of opaline stromatolites from the Chimalacatepec lava tube system, Mexico. Geomicrobiology Journal 36: 694-704. DOI:10.1080/01490451.2019.1607952. 
756

757

758

759

760

761

762

763

764

765

766

767

768

769

770

771

772

773

774

775

776

777

778

779

780

781

782

783

784

785

786

787

788

789

790

791

792

793

794

795
Manolache E, Onac BP. 2000. Geomicrobiology of black sediments in Vantului Cave (Romania): preliminary results. Cave and Karst Science 27: 109-112.

Marín I, Ruiz Arahal D. 2014. The family Beijerinckiaceae. In: Rosenberg E, DeLong EF, Lory S, Stackebrandt E, Thompson F, eds, The Prokaryotes. Alphaproteobacteria and Betaproteobacteria, Berlin: Springer-Verlag, 115-133. DOI:10.1007/978-3-642-30197-1.

Martin-Pozas T, Sanchez-Moral S, Cuezva S, Jurado V, Saiz-Jimenez C, Perez-Lopez R, Carrey R, Otero N, Giesemann A, Well R, Calaforra JM, Fernandez-Cortes A. 2020. Biologically mediated release of endogenous $\mathrm{N}_{2} \mathrm{O}$ and $\mathrm{NO}_{2}$ gases in a hydrothermal, hypoxic subterranean environment. Science of the Total Environment 747: 141218. DOI:10.1016/j.scitotenv.2020.141218.

Miller AZ, De la Rosa JM, Jiménez-Morillo NT, Pereira MFC, Gonzalez-Perez JA, Knicker H, Saiz-Jimenez C. 2020a. Impact of wildfires on subsurface volcanic environments: New insights into speleothem chemistry. Science of the Total Environment 698: 134321. DOI:10.1016/j.scitotenv.2019.134321.

Miller AZ, García-Sánchez AM, Coutinho ML, Pereira MFC, Gázquez F, Calaforra JM, Forti P, Martínez-Frías J, Toulkeridis T, Caldeira AT, Saiz-Jimenez C. 2020b. Colored microbial coatings in show caves from the Galapagos Islands (Ecuador): First microbiological approach. Coatings 10: 1134. DOI:10.3390/coatings10111134.

Miller AZ, Pereira MFC, Calaforra JM, Forti P, Dionísio A, Saiz-Jimenez C. 2014. Siliceous speleothems and associated microbe-mineral interactions from Ana Heva lava tube in Easter Island (Chile). Geomicrobiology Journal 31: 236-245. DOI:

10.1080/01490451.2013.827762.

Molari M, Janssen F, Vonnahme TR, Wenzhöfer F, Boetius A. 2020. The contribution of microbial communities in polymetallic nodules to the diversity of the deep-sea microbiome of the Peru Basin (4130-4198m depth). Biogeosciences 17: 3203-3222. DOI: 10.5194/bg17-3203-2020.

Muñoz-Mérida A, Viguera, E, Claros MG, Trelles O, Pérez-Pulido AJ. 2014. Sma3s: a threestep modular annotator for large sequence datasets. DNA Research 21: 341-353. DOI:10.1093/dnares/dsu001.

Nixon SL, Daly RA, Borton MA, Solden LM, Welch SA, Cole DR, Mouser PJ, Wilkins MJ, Wrighton KC. 2019. Genome-resolved metagenomics extends the environmental distribution of the Verrucomicrobia phylum to the deep terrestrial subsurface. mSphere 4: e00613-19. DOI:10.1128/mSphere.00613-19.

Northup DE, Barns SM, Yu LE, Spilde MN, Schelble RT, Dano KE, Crossey LJ, Connolly CA, Boston PJ, Natvig DO, Dahm CN. 2003. Diverse microbial communities inhabiting ferromanganese deposits in Lechuguilla and Spider Caves. Environmental Microbiology 5: 1071-1086. DOI: 10.1046/j.1462-2920.2003.00500.x.

Northup DE, Connolly C.A, Trent A, Peck VM, Spilde MN, Welbourn WC, Natvig DO. 2004. The nature of bacterial communities in Four Windows Cave, El Malpais National Monument, New Mexico, USA. AMCS Bulletin 19: 119-125. 
796

797

798

799

800

801

802

803

804

805

806

807

808

809

810

811

812

813

814

815

816

817

818

819

820

821

822

823

824

825

826

827

828

829

830

831

832

833

834

835

Northup DE, Melim LA, Spilde MN, Hathaway JJM, Garcia, MG, Moya M, Stone FD, Boston PJ, Dapkevicius MLNE, Riquelme C. 2011. Lava cave microbial communities within mats and secondary mineral deposits: Implications for life detection on other planets. Astrobiology 11: 601-618. DOI:10.1089/ast.2010.0562.

Omoregie AI, Ong DEL, Nissom PM. 2018. Assessing ureolytic bacteria with calcifying abilities isolated from limestone caves for biocalcification. Letters in Applied Microbiology 68: 173-181. DOI:10.1111/lam.13103.

Oren A, Xu X-W. 2014. The family Hyphomicrobiaceae. In: Rosenberg E, DeLong EF, Lory S, Stackebrandt E, Thompson F. eds. The Prokaryotes. Alphaproteobacteria and Betaproteobacteria. Berlin: Springer-Verlag, 247-281. DOI:10.1007/978-3-642-30197-1.

Perkins S. 2020. Core concept: Lava tubes may be havens for ancient alien life and future human explorers. Proceedings of the National Academy of Sciences of the United States of America 117: 17461-17464. DOI:10.1073/pnas.2012176117.

Pershina E, Ivanova E, Kimeklis A, Zverev A, Kichko A, Aksenova T, Andronov E, Abakumov E. 2020. Soil microbiomes of reclaimed and abandoned mines of the Yamal region. Polish Polar Research 41: 95-114. DOI:10.24425/ppr.2020.132571.

Pinto AJ, Marcus DN, Ijaz UZ, Santos QMBL, Dick GJ, Raskin L. 2015. Metagenomic evidence for the presence of comammox Nitrospira-like bacteria in a drinking water system. mSphere 1: e00054-15. DOI:10.1128/mSphere.00054-15.

Popa R, Smith AR, Popa R, Boone J, Fisk M. 2012. Olivine-respiring bacteria isolated from the rock-ice interface in a lava-tube cave, a Mars analog environment. Astrobiology 12: 918. DOI:10.1089/ast.2011.0639.

Porca E, Jurado V, Zgur-Bertok D, Saiz-Jimenez C, Pasic L. 2012. Comparative analysis of yellow microbial communities growing on the walls of geographically distinct caves indicates a common core of microorganisms involved in their formation. FEMS Microbiology Ecology 81: 255-266. DOI:10.1111/j.1574-6941.2012.01383.x

Pratscher J, Vollmers J, Wiegand S, Dumont MG, Kaster A-K 2018. Unravelling the identity, metabolic potential and global biogeography of the atmospheric methane-oxidizing upland soil cluster a. Environmental Microbiology 20: 1016-1029. DOI:10.1111/14622920.14036.

Prosser JI, Head IM, Stein LY. 2014. The family Nitrosomonadaceae. In: Rosenberg E, DeLong EF, Lory S, Stackebrandt E, Thompson F. eds. The Prokaryotes. Alphaproteobacteria and Betaproteobacteria. Berlin: Springer-Verlag, 901-918. DOI:10.1007/978-3-642-30197-1.

Quast C, Pruesse E, Yilmaz P, Gerken J, Schweer T, Yarza P, Peplies J, Glöckner FO. 2013. The SILVA ribosomal RNA gene database project: improved data processing and webbased tools. Nucleic Acids Research 41: D590-D596. DOI:10.1093/nar/gks 1219.

Rippin M, Lange S, Sausen N, Becker B. 2018. Biodiversity of biological soil crusts from the Polar Regions revealed by metabarcoding. FEMS Microbiology Ecology 94: fiy036. DOI:10.1093/femsec/fiy036. 
836

837

838

839

840

841

842

843

844

845

846

847

848

849

850

851

852

853

854

855

856

857

858

859

860

861

862

863

864

865

866

867

868

869

870

871

872

873

874

875

Riquelme C, Hathaway JJM, Dapkevicius MDLNE, Miller AZ, Kooser A, Northup DE, Jurado V, Fernandez O, Saiz-Jimenez C, Cheeptham N. 2015a. Actinobacterial diversity in volcanic caves and associated geomicrobiological interactions. Frontiers in Microbiology 6:1342. DOI: $10.3389 /$ fmicb.2015.01342.

Riquelme C, Rigal F, Hathaway JJM, Northup DE, Spilde MN, Borges PAV, Gabriel R, Amorim IR, Dapkevicius MDLNE. 2015b. Cave microbial community composition in oceanic islands: disentangling the effect of different colored mats in diversity patterns of Azorean lava caves. FEMS Microbiology Ecology 91: fiv141. DOI:10.1093/femsec/fiv141. Rummel PS, Pfeiffer B, Pausch J, Well R, Schneider D, Dittert K. 2020. Maize root and shoot litter quality controls short-term $\mathrm{CO}_{2}$ and $\mathrm{N}_{2} \mathrm{O}$ emissions and bacterial community structure of arable soil. Biogeosciences 17: 1181-1198. DOI:10.5194/bg-17-1181-2020.

Saiz-Jimenez C. 2015. The microbiology of show caves, mines tunnels and tombs: Implications for management and conservation. In: Engel AS, ed. Microbial Life of Cave Systems. Berlin: DeGruiter, pp. 231-261.

Sanchez-Moral S, Portillo MC, Janices I, Cuezva S, Fernández-Cortés A, Cañaveras JC, Gonzalez JM. 2012. The role of microorganisms in the formation of calcitic moonmilk deposits and speleothems in Altamira Cave. Geomorphology 139-140: 285-292. DOI:10.1016/j.geomorph.2011.10.030.

Sharrar AM, Crits-Christoph A, Méheust R, Diamond S, Starr EP, Banfield JF. 2020. Bacterial secondary metabolite biosynthetic potential in soil varies with phylum, depth, and vegetation type. mBio 11:e00416-20. DOI:10.1128/mBio.00416-20.

Simon M, Scheuner C, Meier-Kolthoff JP, Brinkhoff T, Wagner-Döbler I, Ulbrich M, Klenk H-P, Schomburg D, Petersen J, Göker M. 2017. Phylogenomics of Rhodobacteraceae reveals evolutionary adaptation to marine and non-marine habitats. The ISME Journal 11: 1483-1499. DOI:10.1038/ismej.2016.198.

Simpson EH. 1949. Measurement of diversity. Nature 163: 688.

Silva-Lima AW, Froes AM, Garcia GD, Tonon LAC, Swings J, Cosenza CAN, Medina M, Penn K, Thompson JR, Thompson CC, Thompson FL. 2020. Mussismilia braziliensis white plague disease is characterized by an affected coral immune system and dysbiosis. Microbial Ecology. DOI:10.1007/s00248-020-01588-5.

Sjöberg S, Allard B, Rattray JE, Callac N, Grawunder A, Ivarsson M, Sjöberg V, Karlsson S, Skelton A, Dupraz C. 2017. Rare earth element enriched birnessite in water-bearing fractures, the Ytterby mine, Sweden. Applied Geochemistry 78: 158e171. DOI:10.1016/j.apgeochem.2016.12.021.

Snider JR, Moya M, Garcia MG, Spilde MN, Northup DE. 2009. Identification of the microbial communities associated with roots in lava tubes in New Mexico and Hawai'i. Proceedings 15th International Congress of Speleology, vol. 2, pp. 718-723.

Snider J. 2010. Comparison of microbial communities on roots, ceilings and floors of two lava tube caves in New Mexico. M. Sc. Thesis. Albuquerque: The University of New Mexico. https://digitalrepository.unm.edu/biol_etds/103.

PeerJ reviewing PDF | (2021:02:58418:1:1:NEW 7 Apr 2021) 
876

877

878

879

880

881

882

883

884

885

886

887

888

889

890

891

892

893

894

895

896

897

898

899

900

901

902

903

904

905

906

907

908

909

910

911

912

913

914

915

Spilde MN, Northup DE, Boston PJ. 2006. Ferromanganese deposits in the caves of the Guadalupe Mountains. New Mexico Geological Society Guidebook, 57 th Field Conference, Caves and Karst of Southwestern New Mexico, pp. 161-166.

Spilde MN, Northup DE, Caimi NA, Boston PJ, Stone FD, Smith S. 2016. Microbial mat communities in Hawaiian lava caves. International Symposium on Vulcanospeleology 2016. http://www.cavepics.com/IVS17/SPILDE.pdf.

Tomczyk-Żak K, Zielenkiewicz U. 2016. Microbial diversity in caves. Geomicrobiology Journal 33: 20-38. DOI:10.1080/01490451.2014.1003341.

Trias R, Ménez B, le Campion P, Zivanovic Y, Lecourt L, Lecoeuvre A, Schmitt-Kopplin P, Uhl J, Gislason SR, Alfreðsson HA, Mesfin KG, Snæbjörnsdóttir SÓ, Aradóttir ES, Gunnarsson I, Matter JM, Stute M, Oelkers EH, Gérard E. 2017. High reactivity of deep biota under anthropogenic $\mathrm{CO}_{2}$ injection into basalt. Nature Communications 8: 1063. DOI:10.1038/s41467-017-01288-8.

Tsai Y-CC, Lapina MC, Bhushan S, Mueller-Cajar O. 2015. Identification and characterization of multiple rubisco activases in chemoautotrophic bacteria. Nature Communications 6: 8883. DOI:10.1038/ncomms9883.

UniProt Consortium. 2019. UniProt: a worldwide hub of protein knowledge. Nucleic Acids Research 47: D506-D515. DOI:10.1093/nar/gky1049.

Vaccarelli I, Matteucci F, Pellegrini M, Bellatreccia F, Del Gallo M. 2021. Exploring microbial biosignatures in Mn-deposits of deep biosphere: A preliminary cross-disciplinary approach to investigate geomicrobiological interactions in a cave in Central Italy. Frontiers in Earth Science 9:590257. DOI: 10.3389/feart.2021.590257.

Vorholt JA, Chistoserdova L, Lidstrom ME, Thauer RK. 1998. The NADP-dependent methylene tetrahydromethanopterin dehydrogenase in Methylobacterium extorquens AM1. Journal of Bacteriology 180: 5351-5356.

Wang P, Marsh EL, Ainsworth EA, Leakey ADB, Sheflin AM, Schachtman DP. 2017. Shifts in microbial communities in soil, rhizosphere and roots of two major crop systems under elevated $\mathrm{CO}_{2}$ and $\mathrm{O}_{3}$. Scientific Reports 7: 15019. DOI:10.1038/s41598-017-14936-2.

Warnes GR, Bolker B, Bonebakker L, Gentleman R, Liaw WHA, Lumley T, Maechler M, Magnusson A, Moeller S, Schwartz M, Venables B, Galili T. 2016. GPLOTS: Various R Programming Tools for Plotting Data. R Package, version 3.1.1; GitHub, Inc.: San Francisco, CA, USA, Available online: http://cran.rproject.org/web/packages/gplots/index.html (accessed on 24 February 2021).

Webster KD, Schimmelmann A, Drobniak A, Mastalerz M, Rosales Lagarde L, Boston PJ, Lennon JT. 2018. Diversity and composition of cave methanotrophic communities. bioRxiv preprint, DOI: https://DOI.org/10.1101/412213.

Wiseschart A, Mhuantong W, Tangphatsornruang S, Chantasingh D, Pootanakit K. 2019.

Shotgun metagenomic sequencing from Manao-Pee cave, Thailand, reveals insight into the microbial community structure and its metabolic potential. BMC Microbiology 19: 144. DOI:10.1186/s12866-019-1521-8. 
916 Wu ML, van Teeseling MCF, Willems MJR, van Donselaar EG, Klingl A, Rachel R, Geerts

917

918

919

920

921

922

923

924

925

926

927

928

929

930

931

932

933

934

935

936

937

938

939

940

941

942

943

944

945 WJC, Jetten MSM, Strous M, van Niftrik L. 2012. Ultrastructure of the denitrifying methanotroph "Candidatus Methylomirabilis oxyfera," a novel polygon-shaped bacterium. Journal of Bacteriology 194: 284-291. DOI:10.1128/JB.05816-11.

Yang Z, Xiao X, Zhang Y. 2020. Microbial diversity of sediments from an inactive hydrothermal vent field, Southwest Indian Ridge. Marine Life Science \& Technology 2: 73-86. DOI:10.1007/s42995-019-00007-0.

Zarraonaindia I, Owens SM, Weisenhorn P, West K, Hampton-Marcell J, Lax S, Bokulich NA, Mills DA, Martin G, Taghavi S, van der Lelie D, Gilbert JA. 2015. The soil microbiome influences grapevine-associated microbiota. mBio 6: e2527-14.

DOI:10.1128/mBio.02527-14.

Zeng Y., Baumbach J, Barbosa EGV, Azavedo V, Zhang C, Koblížek M. 2016. Metagenomic evidence for the presence of phototrophic Gemmatimonadetes bacteria in diverse environments. Environmental Microbiology Reports 8: 139-149. DOI:10.1111/17582229.12363.

Zhang J, Kobert K, Flouri T, Stamatakis A. 2014. PEAR: a fast and accurate Illumina PairedEnd reAd mergeR. Bioinformatics 30: 614-620. DOI:10.1093/bioinformatics/btt593.

Zhu T, Dittrich M. 2016. Carbonate precipitation through microbial activities in natural environment, and their potential in biotechnology: A review. Frontiers in Bioengineering and Biotechnology 4: 4. DOI:10.3389/fbioe.2016.00004.

Zhu H-Z, Zhang Z-F, Zhou N, Jiang C-Y, Wan B-J, Cai L, Liu S-J. 2019. Diversity, distribution and co-occurrence patterns of bacterial communities in a karst cave system. Frontiers in Microbiology 10: 1726. DOI: 10.3389/fmicb.2019.01726.

Zimmermann J, Gonzalez JM, Saiz-Jimenez C, Ludwig W. 2005. Detection and phylogenetic relationships of highly diverse uncultured acidobacterial community on paleolithic paintings in Altamira Cave using 23S rRNA sequence analyses. Geomicrobiology Journal 22: 379-388. DOI:10.1080/01490450500248986. 
Figure 1

Map of Fuente de la Canaria Cave, La Palma Island

Figure 1. Planimetry and cross-section of Fuente de la Canaria Cave

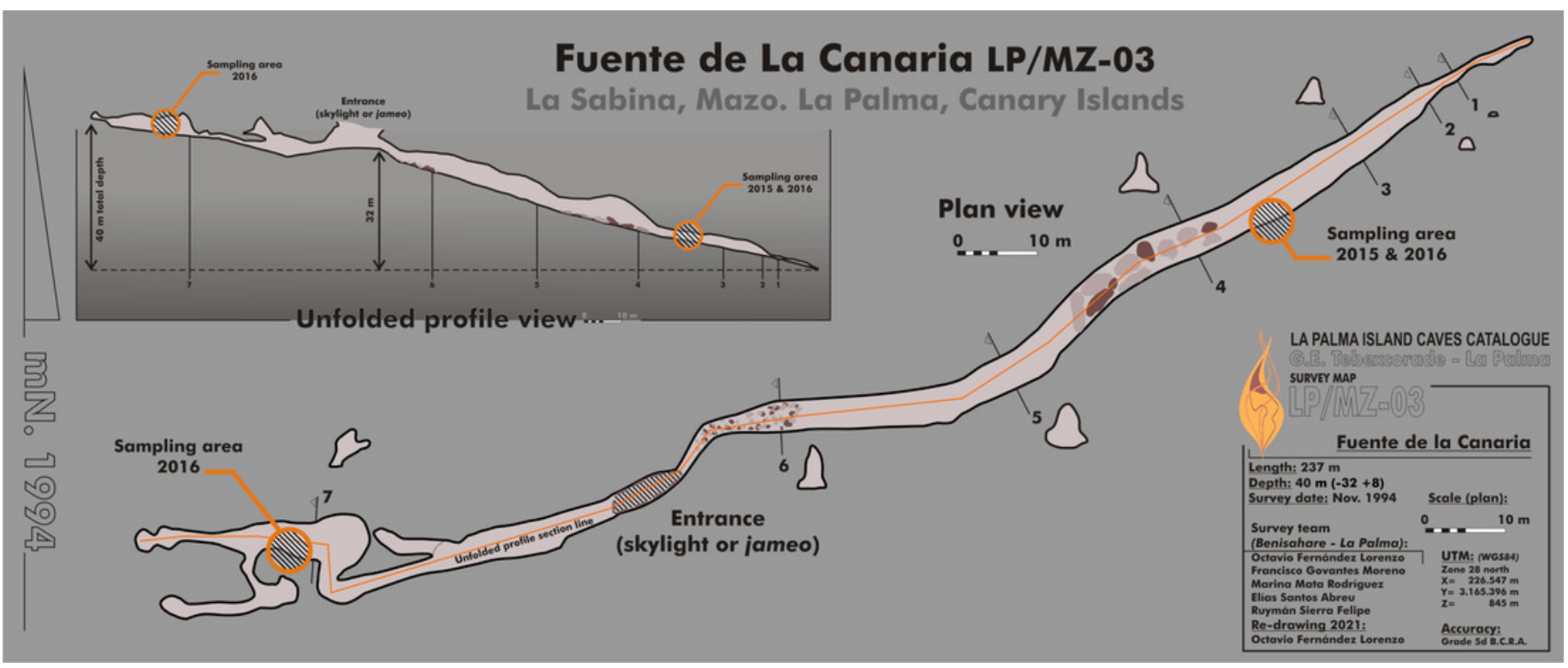


Figure 2

Samples collected from Fuente de la Canaria Cave

Figure 2. Field images of the mineral deposits and colored microbial colonies collected from

Fuente de la Canaria Cave (MZ03) in La Palma Island (Spain). (A) sample MZ03-2B. (B)

sample MZ03-3C. (C) sample MZ03-8H. (D) sample MZ03-10J.
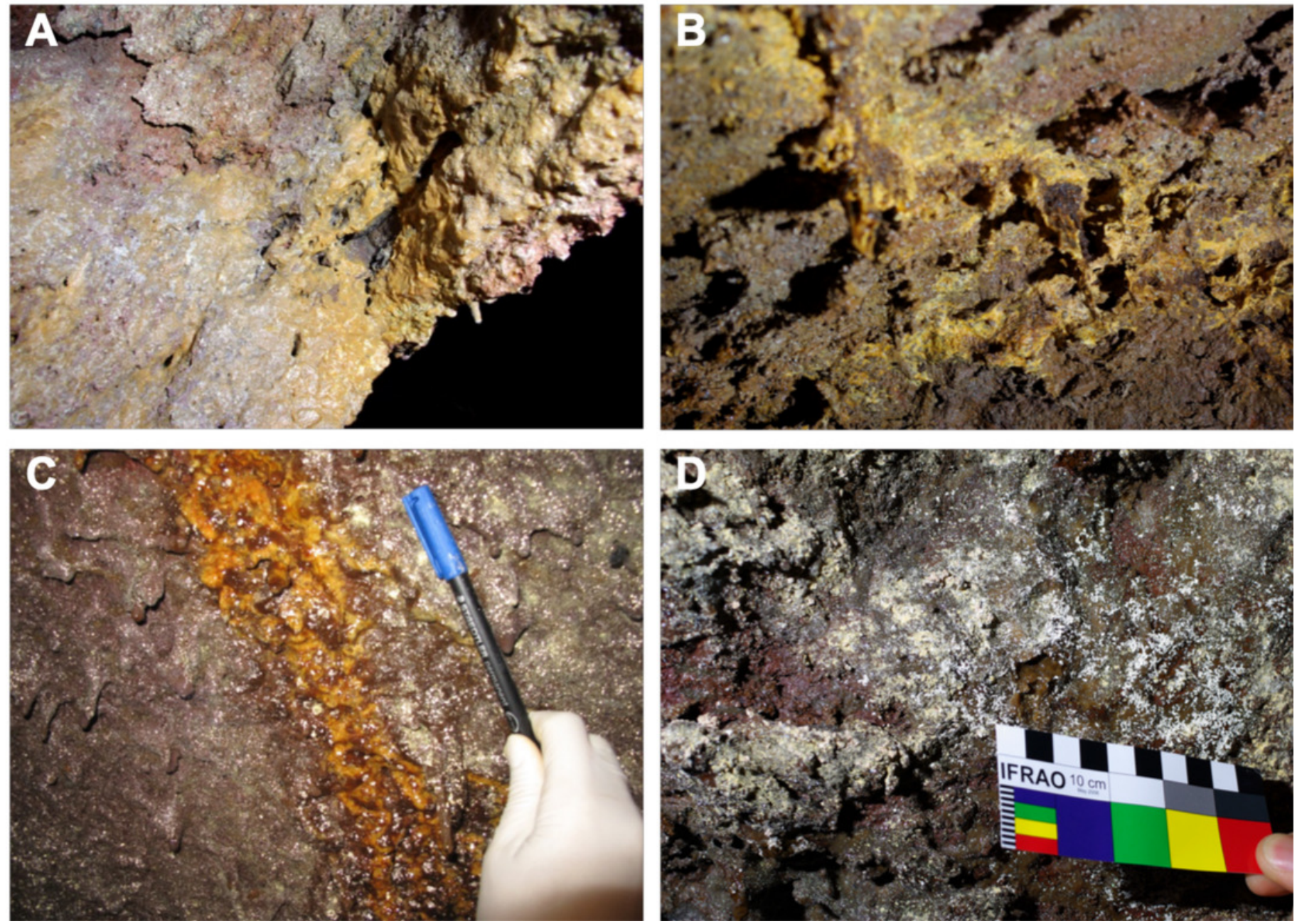


\section{Figure 3}

Field Emission Scanning Electron Microscopy images of samples,

Figure 3. Representative Field Emission Scanning Electron Microscopy images of the studied samples, depicting $A, B$ : Clusters of Actinobacteria-like cells with spiny surface ornamentation in the mucous formation of ochre color (MZ03-2B); C: Microbial filaments probably of Actinobacteria in the ochre soft stalactite (MZ03-3C); D: Hollow bacterial filament on the sample surface of the ochre soft stalactite (MZ03-3C); E: Prosthecate-like bacterial cell in the ochre mucous deposit on a rock crack with water runoff (MZ03-8H); F: Dense network of nano-scaled filaments in the ochre mucous deposit on a rock crack with water runoff (MZ03-8H); G: Mass of interwoven filaments, and H: Coccoid-shaped cells with smooth surfaces in the mineral formation with abundant moonmilk deposits (MZ03-10J). 

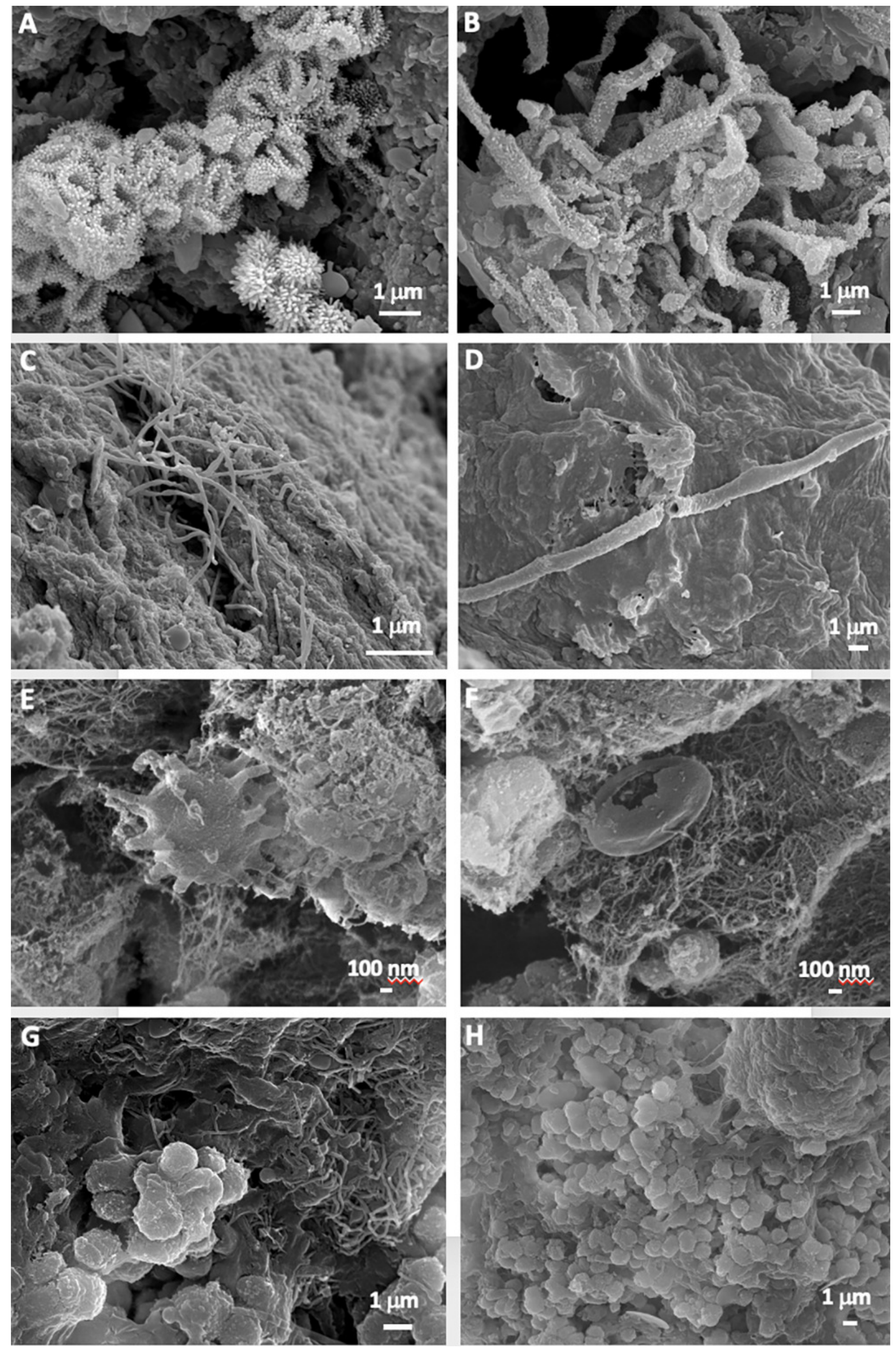
Figure 4

Taxonomic identifications of Bacteria at class level

Figure 4. Heat-map analysis of Fuente de la Canaria Cave with taxonomic identifications of Bacteria at class level. The classes are described in the right column and their respective abundances included in the boxes. Colored left bar groups the classification at phylum level. 


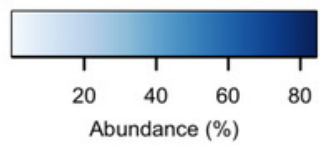

80
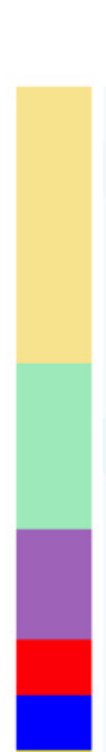

Taxonomic distribution at class level

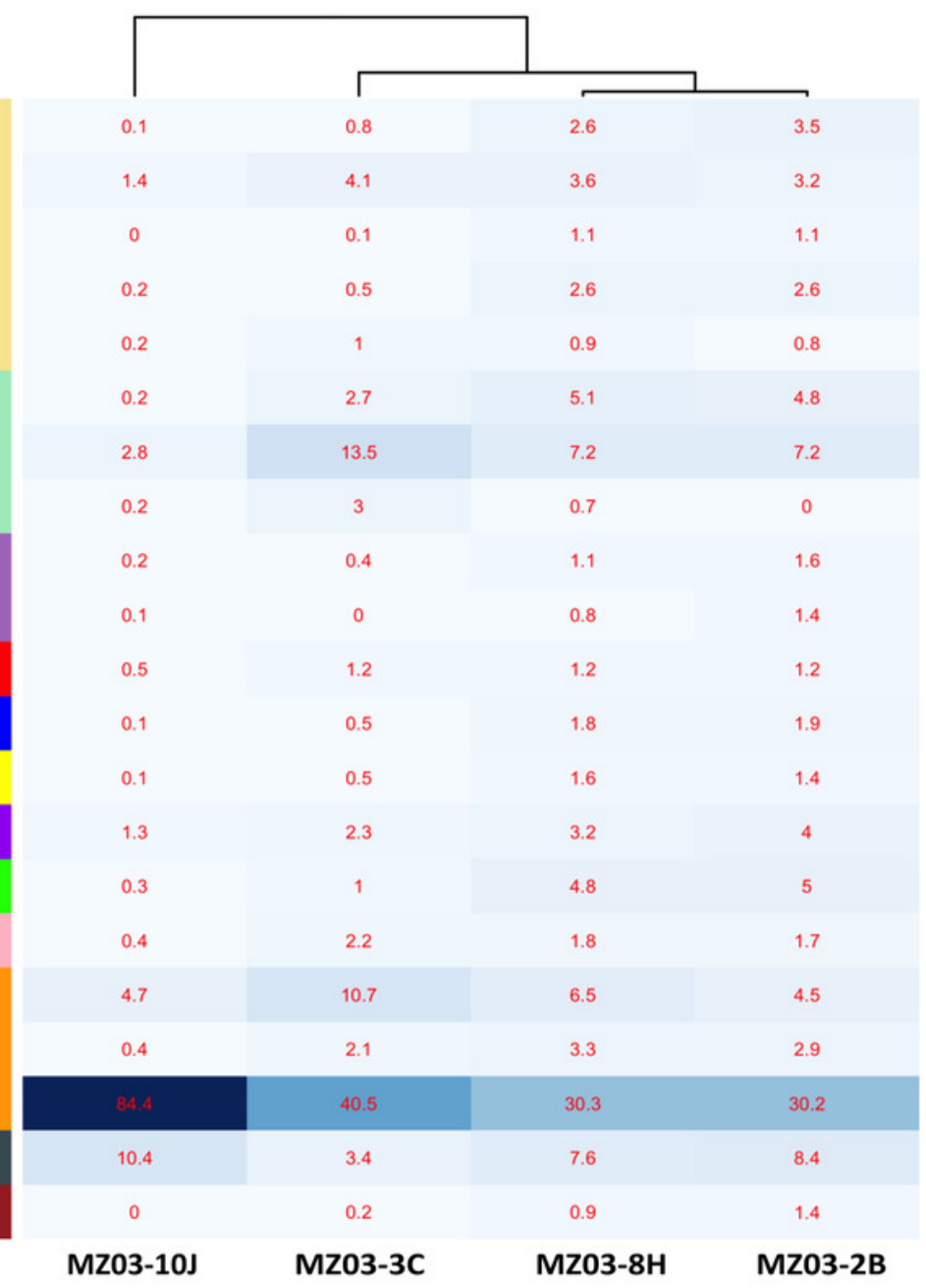

Acidobacteriia

Blastocatellia (Subgroup 4)

Holophagae

Subgroup 17

Subgroup 6

Acidimicrobiia

Actinobacteria

Nitriliruptoria

Bacteroidia

Ignavibacteria

Anaerolineae

Dadabacteriia

Uncultured bacterium

Nitrospira

Gemmatimonadetes

Planctomycetacia

Alphaproteobacteria

Deltaproteobacteria

Gammaproteobacteria

NC10

Verrucomicrobiae

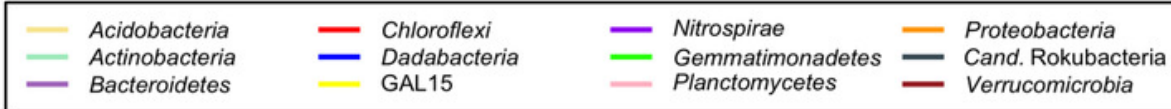


Figure 5

Taxonomic identifications of Bacteria at family/genus level.

Figure 5. Heat-map analysis of Fuente de la Canaria Cave with taxonomic identifications of Bacteria at family/genus level. The families/genera are described in the right column and their respective abundances included in the boxes. Colored left bar groups the classification at order level. 


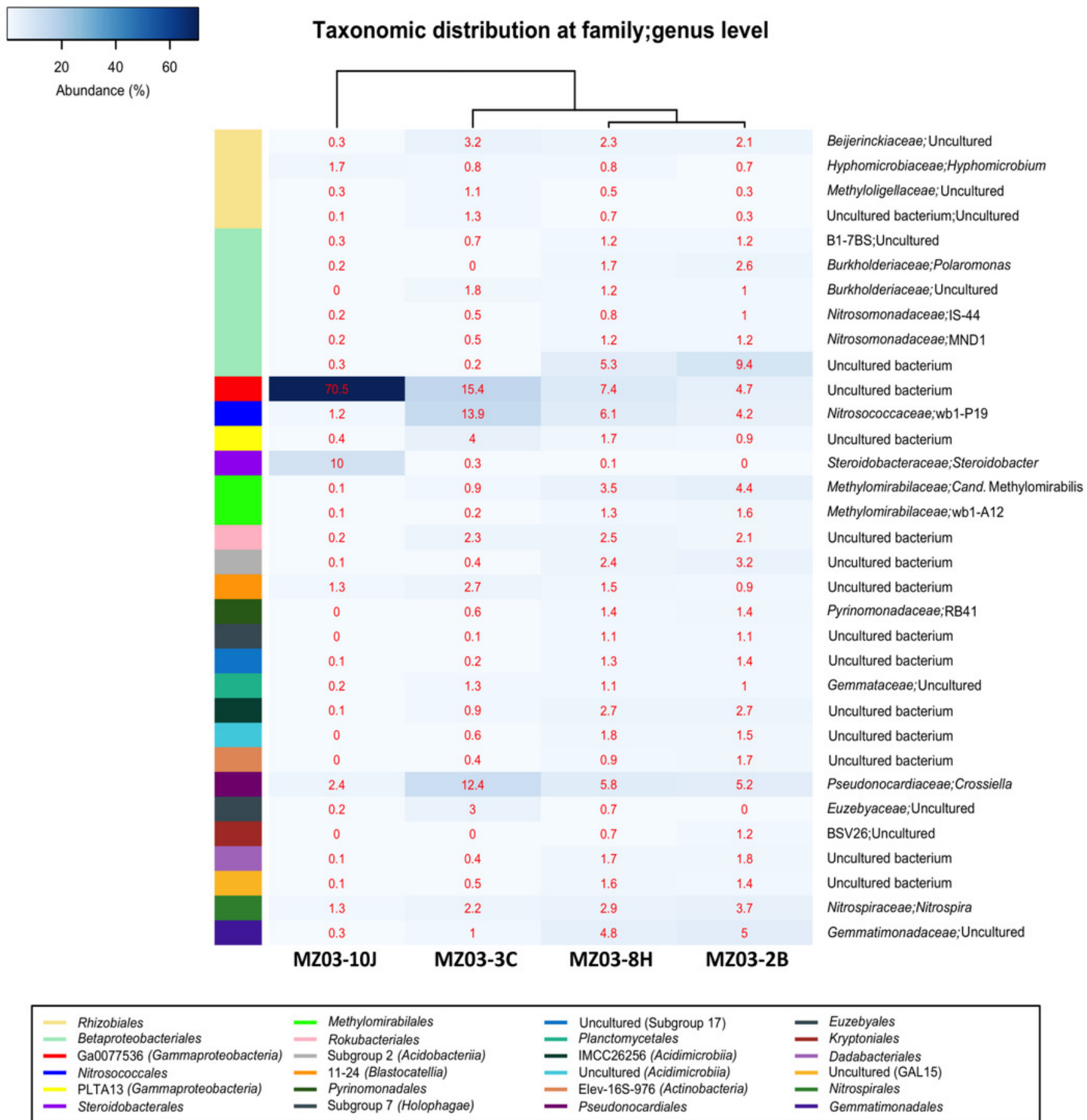


Figure 6

Predicted ecological functions of Bacteria

Figure 6. Relative abundance of FAPROTAX predicted ecological functions ( $Y$ axis) of Fuente de la Canaria Cave. The size of the cycles indicates the relative abundance. 
chemoheterotrophy
aerobic chemoheterotrophy nitrification

aerobic nitrite oxidation aerobic ammonia oxidation methylotrophy

hydrocarbon degradation methanotrophy

predatory or exoparasitic respiration of sulfur compounds sulfate respiration phototrophy photoautotrophy

intracellular parasites oxygenic photoautotrophy cyanobacteria ureolysis

anoxygenic photoautotrophy anoxygenic photoautotrophy S oxidizing nitrate reduction aromatic compound degradation nitrogen respiration nitrate respiration animal parasites or symbionts human associated human pathogens all fermentation nitrite respiration denitrification

nitrous oxide denitrification nitrite denitrification nitrate denitrification photoheterotrophy manganese oxidation chitinolysis plant pathogen nitrogen fixation dark hydrogen oxidation cellulolysis chloroplasts methanogenesis methanol oxidation dark oxidation of sulfur compounds dark thiosulfate oxidation dark sulfur oxidation dark sulfide oxidation human pathogens pneumonia reductive acetogenesis invertebrate parasites chlorate reducers plastic degradation knallgas bacteria dissimilatory arsenate reduction arsenate detoxification
O MZO3-3C
O $\mathrm{MZO3-8H}$
O MZ03-2B
O MZ03-10J

Relative Abundance (\%)
- 1
○ 5
○ 10
○ 20
30
40 


\section{Figure 7}

Predicted genes encoding enzymes

Figure 7. Heat-map showing the relative abundances of PICRUSt2 predicted genes (Y axis) encoding the enzymes involved in methane, sulfur, nitrogen metabolism and $\mathrm{CO}_{2}$ fixation based on Metacyc database for each sampling point ( $X$ axis). The values for functional groups are marked by colors from white to red designating the least abundant to most abundant. 
Relative abundance (\%)

\begin{tabular}{|c|c|c|c|}
\hline 0.00 & 0.01 & 0.01 & $\frac{1}{0.01}$ \\
\hline 0.07 & 0.02 & 0.02 & 0.01 \\
\hline 0.00 & 0.00 & 0.00 & 0.00 \\
\hline 0.00 & 0.00 & 0.00 & 0.00 \\
\hline 0.00 & 0.01 & 0.01 & 0.01 \\
\hline 0.00 & 0.01 & 0.01 & 0.02 \\
\hline 0.00 & 0.02 & 0.01 & 0.01 \\
\hline 0.00 & 0.01 & 0.01 & 0.01 \\
\hline 0.00 & 0.00 & 0.00 & 0.00 \\
\hline 0.00 & 0.00 & 0.00 & 0.00 \\
\hline 0.00 & 0.00 & 0.00 & 0.00 \\
\hline 0.00 & 0.00 & 0.00 & 0.00 \\
\hline 0.00 & 0.00 & 0.00 & 0.00 \\
\hline 0.00 & 0.00 & 0.00 & 0.00 \\
\hline 0.00 & 0.00 & 0.00 & 0.00 \\
\hline 0.00 & 0.00 & 0.00 & 0.00 \\
\hline 0.00 & 0.00 & 0.00 & 0.00 \\
\hline 0.00 & 0.00 & 0.00 & 0.00 \\
\hline
\end{tabular}

\begin{tabular}{|l|l|l|l|}
\hline 0.11 & 0.11 & 0.08 & 0.07 \\
\hline 0.24 & 0.26 & 0.24 & 0.24 \\
\hline 0.05 & 0.09 & 0.08 & 0.09 \\
\hline 0.05 & 0.06 & 0.06 & 0.07 \\
\hline 0.00 & 0.00 & 0.00 & 0.00 \\
\hline 0.14 & 0.04 & 0.02 & 0.01 \\
\hline 0.00 & 0.00 & 0.00 & 0.00 \\
\hline
\end{tabular}

\begin{tabular}{|l|l|l|l|}
\hline 0.37 & 0.12 & 0.10 & 0.10 \\
\hline 0.08 & 0.04 & 0.03 & 0.03 \\
\hline 0.00 & 0.01 & 0.01 & 0.01 \\
\hline 0.32 & 0.14 & 0.10 & 0.08 \\
\hline 0.17 & 0.18 & 0.22 & 0.22 \\
\hline 0.17 & 0.16 & 0.18 & 0.18 \\
\hline 0.17 & 0.12 & 0.14 & 0.15 \\
\hline 0.00 & 0.00 & 0.00 & 0.00 \\
\hline 0.13 & 0.16 & 0.17 & 0.17 \\
\hline 0.00 & 0.00 & 0.00 & 0.00 \\
\hline 0.00 & 0.00 & 0.00 & 0.00 \\
\hline 0.38 & 0.43 & 0.43 & 0 \\
\hline 0.13 & 0.17 & 0.17 & 0.17 \\
\hline 0.03 & 0.14 & 0.12 & 0.11 \\
\hline 0.00 & 0.00 & 0.00 & 0.00 \\
\hline 0.00 & 0.00 & 0.00 & 0.00 \\
\hline 0.00 & 0.00 & 0.00 & 0.00 \\
\hline 0.00 & 0.00 & 0.00 & 0.00 \\
\hline 0.12 & 0.10 & 0.08 & 0.07 \\
\hline 0.20 & 0.19 & 0.17 & 0.17 \\
\hline
\end{tabular}

\begin{tabular}{|l|l|l|l|}
\hline 0.00 & 0.01 & 0.01 & 0.02 \\
\hline
\end{tabular}

\begin{tabular}{|l|l|l|l|}
\hline 0.00 & 0.01 & 0.01 & 0.02 \\
\hline 0.21 & 0.08 & 0.05 & 0.03 \\
\hline 0.25 & 0.25 & 0.23 & 0.23 \\
\hline 0.25 & 0.25 & 0.23 & 0.23 \\
\hline 0.04 & 0.04 & 0.02 & 0.02 \\
\hline
\end{tabular}

\begin{tabular}{|l|l|l|l|}
\hline 0.04 & 0.04 & 0.02 & 0.02 \\
\hline 0.01 & 0.04 & 0.06 & 0.07 \\
\hline 0.01 & 0.02 & 0.02 & 0.03 \\
\hline
\end{tabular}

\begin{tabular}{l|l|l|l}
\hline 0.01 & 0.02 & 0.02 & 0.03 \\
\hline 0.00 & 0.01 & 0.02 & 0.02 \\
\hline
\end{tabular}

\begin{tabular}{l|l|l|l}
\hline 0.00 & 0.01 & 0.02 & 0.02 \\
\hline 0.04 & 0.08 & 0.08 & 0.09 \\
\hline
\end{tabular}

\begin{tabular}{|l|l|l|l|}
\hline 0.00 & 0.01 & 0.02 & 0.03 \\
\hline 0.00 & 0.00 & 0.00 & 0.00 \\
\hline
\end{tabular}

\begin{tabular}{l|l|l|l}
0.00 & 0.00 & 0.00 & 0.00 \\
\hline 0.00 & 0.00 & 0.01 & 0.01 \\
\hline
\end{tabular}

\begin{tabular}{l|l|l|l|}
\hline 0.00 & 0.00 & 0.00 & 0.00 \\
\hline 0.00 & 0.01 & 0.00 & 0.00 \\
\hline 0.00 & 0.00 & 0.00 & 0.00 \\
\hline
\end{tabular}

\begin{tabular}{|l|l|l|l|}
\hline 0.00 & 0.00 & 0.00 & 0.00 \\
\hline 0.07 & 0.02 & 0.02 & 0.01 \\
\hline
\end{tabular}

\begin{tabular}{|l|l|l|l|}
\hline 0.07 & 0.02 & 0.02 & 0.01 \\
\hline 0.04 & 0.11 & 0.11 & 0.12 \\
\hline 0.00 & 0.00 & 0.01 & 0.01 \\
\hline
\end{tabular}

\begin{tabular}{|l|l|l|l|}
\hline 0.00 & 0.00 & 0.01 & 0.01 \\
\hline 0.00 & 0.00 & 0.00 & 0.01 \\
\hline 0.23 & 0.13 & 0.08 & 0.06 \\
\hline
\end{tabular}

\begin{tabular}{|l|l|l|l}
\hline 0.23 & 0.13 & 0.08 & 0.06 \\
\hline 0.00 & 0.01 & 0.01 & 0.01 \\
\hline 0.00 & 0.00 & 0.01 & 0.01 \\
\hline 0.16 & 0.23 & 0.23 & 0.23 \\
\hline
\end{tabular}

\begin{tabular}{l|l|l|l}
0.00 & 0.00 & 0.01 & 0.01 \\
\hline 0.16 & 0.23 & 0.23 & 0.23 \\
\hline
\end{tabular} $\begin{array}{lllll}0.4 & 0.3 & 0.2 & 0.1 & 0\end{array}$

Methane metabolism

EC:4.2.1.147: 5,6,7,8-tetrahydromethanopterin hydro-lyase

EC:1.12.98.1: Coenzyme F420 hydrogenase

EC:2.8.4.1: Coenzyme-B sulfoethylthiotransferase

EC:1.5.8.1: Dimethylamine dehydrogenase

EC:2.3.1.101: Formylmethanofuran--tetrahydromethanopterin $\mathrm{N}$-formyltransferase

EC:1.14.18.3: Methane monooxygenase (particulate)

EC:1.1.2.7: Methanol dehydrogenase (cytochrome c)

EC:3.5.4.27: Methenyltetrahydromethanopterin cyclohydrolase

EC:1.4.9.1: Methylamine dehydrogenase (amicyanin)

EC:1.5.98.1: Methylenetetrahydromethanopterin dehydrogenase

EC:2.1.1.246: methyltransferase

EC:4.4.1.22: S-(hydroxymethyl)glutathione synthase

EC:2.1.1.86: Tetrahydromethanopterin S-methyltransferase

EC:1.5.8.2: Trimethylamine dehydrogenase

EC:1.14.13.148: Trimethylamine monooxygenase

EC:1.7.2.3: Trimethylamine-N-oxide reductase (cytochrome c)

EC:2.1.1.250: [Trimethylamine--corrinoid protein] Co-methyltransferase

EC:1.14.13.25: Methane monooxygenase (soluble)

Sulfur metabolism

EC:2.7.1.25: adenylyl-sulfate kinase

EC:2.7.7.4: sulfate adenylyltransferase

EC:1.8.4.8: phosphoadenylyl-sulfate reductase (thioredoxin)

EC:1.8.1.2: sulfite reductase (NADPH) hemoprotein

EC:1.8.99.1: sulfite reductase

EC:1.8.99.5: dissimilatory sulfite reductase

EC:7.3.2.3 : ABC-type sulfate transporter

$\mathrm{CO}_{2}$ Fixation

EC:4.1.1.39: ribulose-bisphosphate carboxylase

EC:2.7.1.19: Phosphoribulokinase

EC:2.3.3.8: ATP citrate (pro-S)-lyase.

EC:1.3.5.4: fumarate reductase (quinol)

EC:1.2.7.3: 2-ketoglutarate ferredoxin oxidoreductase

EC:1.2.7.11: 2-oxoacid ferredoxin oxidoreductase

EC:1.2.7.1: Pyruvate ferredoxin oxidoreductase

EC:1.2.7.4: anaerobic carbon-monoxide dehydrogenase

EC:6.2.1.1: acetyl-CoA synthase

EC:1.3.1.6: fumarate reductase subunit

EC:1.17.1.10: formate dehydrogenase (NADP+) alpha subunit

EC:6.4.1.2: acetyl-CoA carboxylase

EC:6.3.4.14: biotin carboxylase subunit

EC:6.4.1.3: propionyl-CoA carboxylase

EC:2.1.3.15: acetyl-CoA carboxytransferase.

EC:1.2.1.75: malonyl-CoA reductase

EC:1.2.1.76: succinyl-CoA reductase (NADPH)

EC: 1.1.1.298: 3-hydroxypropionate dehydrogenase (NADP+)

EC:4.1.1.31: Phosphoenolpyruvate carboxylase

EC:4.2.1.1: beta-class carbonic anhydrase

Nitrogen metabolism

EC:1.14.99.39: Ammonia monooxygenase

EC:1.18.6.1: Nitrogenase

EC:1.4.1.13: Glutamate synthase (NADPH)

EC:1.4.1.14: Glutamate synthase (NADH)

EC:1.4.1.2: Glutamate dehydrogenase

EC:1.4.1.3: Glutamate dehydrogenase $(\operatorname{NAD}(P)(+))$

EC:1.4.1.4: Glutamate dehydrogenase (NADP $(+)$ )

EC:1.4.7.1: Glutamate synthase (ferredoxin)

EC:1.7.1.15: Nitrite reductase (NADH)

EC:1.7.2.1: Nitrite reductase (NO-forming)

EC:1.7.2.2: Nitrite reductase (cytochrome; ammonia-forming)

EC:1.7.2.4: Nitrous-oxide reductase

EC:1.7.2.5: Nitric-oxide reductase (cytochrome c)

EC:1.7.7.1: Ferredoxin--nitrite reductase

EC:1.7.7.2: Ferredoxin--nitrate reductase

EC:1.7.99.1: Hydroxylamine reductase

EC:1.7.99.4: Nitrate reductase

EC:2.7.2.2: Carbamate kinase

EC:3.5.1.49: Formamidase

EC:3.5.1.5: Urease

EC:4.2.1.104: Cyanase

EC:4.3.1.1: Aspartate ammonia-lyase

EC:6.3.1.2: Glutamate-ammonia ligase 
Table $\mathbf{1}$ (on next page)

Indices of microbial community

Table 1 . Alpha diversity indices for microbial community 165 rRNA amplicon libraries in Fuente de la Canaria Cave 
1

2 Table 1. Alpha diversity indices for microbial community 16S rRNA amplicon libraries in

3 Fuente de la Canaria Cave

\begin{tabular}{cccccc}
\hline Samples & Simpson & Shannon & Observed species & ACE & Chaol \\
\hline MZ03-3C & 0.973 & 8.736 & 20511 & 22006.842 & 20973.610 \\
MZ03-8H & 0.991 & 9.459 & 20882 & 25515.708 & 23178.711 \\
MZ03-2B & 0.993 & 10.063 & 21191 & 24162.354 & 22347.636 \\
MZ03-10J & 0.706 & 5.033 & 4650 & 5752.039 & 5290.068 \\
\hline
\end{tabular}

4 
Table 2 (on next page)

Prokariotic distribution in the cave

Table 2. Prokaryotic OTUs distribution in Fuente de la Canaria Cave 
1

2

3 Table 2. Prokaryotic OTUs distribution in Fuente de la Canaria Cave

\begin{tabular}{lllll}
\hline Domain & MZ03-2B & MZ03-3C & MZ03-8H & MZ03-10J \\
\hline Archaea & 0.339 & 0.179 & 0.303 & 0.036 \\
Bacteria & 99.789 & 99.805 & 99.641 & 99.959 \\
Unassigned & 0.073 & 0.016 & 0.056 & 0.005 \\
\hline
\end{tabular}

4 


\section{Table 3(on next page)}

Major bacterial phyla in the cave

Table 3. Major bacterial phyla in samples from Fuente de la Canaria Cave 
2 Table 3. Major bacterial phyla in samples from Fuente de la Canaria Cave

\begin{tabular}{lcccc}
\hline Phylum & MZ03-2B & MZ03-3C & MZ03-8H & MZ03-10J \\
\hline Acidobacteria & 12.557 & 7.684 & 12.260 & 2.486 \\
Actinobacteria & 13.259 & 20.236 & 14.292 & 3.452 \\
Bacteroidetes & 2.971 & 0.377 & 1.897 & 0.312 \\
Chloroflexi & 3.896 & 3.370 & 4.169 & 0.838 \\
Dadabacteria & 1.916 & 0.468 & 1.760 & 0.081 \\
GAL15 & 1.358 & 0.486 & 1.607 & 0.111 \\
Gemmatimonadetes & 5.018 & 1.006 & 4.795 & 0.277 \\
Nitrospirae & 4.037 & 2.301 & 3.238 & 1.302 \\
Patescibacteria & 1.255 & 0.521 & 0.894 & 0.031 \\
Planctomycetes & 2.835 & 3.982 & 3.141 & 0.635 \\
Proteobacteria & 37.635 & 53.342 & 40.101 & 89.451 \\
Candidatus Rokubacteria & 8.415 & 3.400 & 7.594 & 0.416 \\
Verrucomicrobia & 1.403 & 0.182 & 0.941 & 0.041 \\
Others $(<1 \%)$ & 3.234 & 2,450 & 2.952 & 0.526 \\
\hline
\end{tabular}

3

4 